\title{
A review of pharmaceuticals and endocrine-disrupting compounds: sources, effects, removal, and detections
}

Jimoh O. Tijani, Ojo O. Fatoba and Leslie. F. Petrik

\begin{abstract}
There are growing concerns about the increasing trends of emerging micropollutants in the environment due to their potential negative impacts on natural ecosystems and humans. This has attracted attention from both governmental and non-governmental organisations worldwide. Pharmaceuticals, personal care products, and endocrine disruptors are continuously being released consciously or unconsciously into water sources due to poor regulatory frameworks especially in the developing countries. The effects of these contaminants are poorly known. They are not easily biodegradable and have become an environmental nuisance and public health issue. This has heightened the risk of exposure to their deleterious effects in such countries where the majority of the population are still struggling to have access to good quality drinking water supplies and better sanitation. With the rising fear of short- and long-term impacts of the ever-increasing number of persistent recalcitrant organic compounds accumulating in the environment, their removal is gradually becoming an issue to the water treatment industry. Hence, there is a need to develop functional techniques for the management of water contaminated by these emerging contaminants so as to increase the availability and access to safe and good-quality drinking water. We conducted a narrative review on these emerging micropollutants and examined their various documented sources, effects, as well as recent techniques for their effective removal. This becomes necessary due to the increasing occurrence of these pollutants in the aquatic and terrestrial environment. These levels are expected to further increase in the coming years as a consequence of the ever-increasing population density which undoubtedly characterizes developing economies. Our findings show that the present reported treatment techniques in the literature such as biological oxidation/biodegradation, coagulation/flocculation, ozonation, el ectrodialysis, reverse osmosis, sedimentation, filtration, and activated carbon were not designed for removal of these newly identified contaminants, and as such, the techniques are not sufficient and unable to completely degrade the compounds. We therefore recommended the need for concerted efforts to develop better techniques, especially combined advanced oxidative methods to address the shortcomings of and growing challenge to current practices.
\end{abstract}




\section{Introduction}

The importance of good-quality, potable water to human existence cannot be underestimated, and life will be practically impossible or difficult without the availability of safe drinking water (Swaminathan et al. 2013; Cortés Muñoz et al. 2013). Over the last few decades, there have been tremendous improvements in the supply of safe drinking water to growing populations. This is through various governmental interventions especially in developing countries that want to meet the Millennium Development Goal target of 2015 adopted by United Nations in 2000. This mandate is in line with European Commission Water Framework Directive article 4 that states that all community waters such as $\mathrm{s}$ urface, ground, transitional, and coastal must be in good status by 2015 (Belgiorno et al. 2007). However, good-quality drinking water is being threatened as a consequence of various natural and anthropogenic inputs involving the discharge of effluents containing priority and emerging micropollutants that are ubiquitous in different receiving water sources. The emerging contaminants include persistent organic pollutants, micro-constituents, cyanotoxins, pesticides and herbicides, disinfection by-products, endocrine-disrupting chemicals (EDCs), pharmaceuticals and personal care products (PPCPs), and a host of other compounds. The rapid technological advancement, rapid increase in human population, inadequate wastewater treatment facilities, poor agricultural practices, inadequate land-use acts, and rapid urbanization coupled with drought occasioned by global climate change have created water pollution problems on a level that have not been seen before (Mara 2003; Moore et al. 2003; Montgomery and Elimelech 2007; Johnson et al. 2008). Almost every industrial process involves the production and release of huge quantities of half a dozen or more of those mentioned pollutants in one form or the other into the aquatic and terrestrial environment. The most frequent occurrence is the increasing accumulation of pharmaceuticals and endocrine-disrupting compounds that have overloaded and tainted the various receiving water bodies (Lindqvist et al. 2005; Kasprzyk-Hordern et al. 20 09). The build-up and detection of high concentrations of these micropollutants in aquatic environments has made water unsafe for aquatic animals and for human consumption (Moldovan 2006; Roberts and Thomas 2006; Tamtam et al. 2008; Liu et al. 2009). The number of these emerging contaminants is still expected to increase in treated wastewater due to higher population density. This has resulted in growing public health risks in the developing countries where impacts have been noted such as endocrine conduit disturbance in aquatic organisms, brain damage, convulsion, carcinogenic diseases, reproductive behavioral disorder, cardiovascular disease, liver damage, and lung defects as well as disturbances in gene expression resulting in feminization of aquatic organisms (Mastin 2005; Samir et al. 2006; Campbell et al. 2006; Ha et al. 2007; Diamanti-Kandarakis et al. 2009). The current scenario has become worse due to the lack of adequate and efficient water treatment facilities capable of effectively eliminating and degrading the toxic and recalcitrant compounds to harmless substances (Nakada et al. 2006; Gulkowska et al. 2008; Sui et al. 2010). The deterioration of water quality seriously affects economic progress and impacts negatively on the sustainable development of a nation (Rahman et al. 2009a, b). Therefore, in order to have a healthy population and better society with a consequential effect on the economy growth and sustainability, access to safe drinking water and functional wastewater treatment facilities should not be compromised.

\section{http://repository.uwc.ac.za}


Within the last 10-15 years, different analytical techniques for the detection and quantification of persistent organic contaminants at environmentally low concentrations have been developed (Ternes and Joss 2006). This was as a consequence of the increasing discovery of PPCPs/EDCs in environmental matrices (Kolpin et al. 2002; Tixier et al. 2003; Ashton et al. 2004). Authors such as (Yoon and Lueptow 2005) and (Yoon et al. 2006a, b) separately observed that high pollution levels in the aquatic environment were majorly attributed to the presence of low concentrations of EDCs and PPCPs (nanograms per liter). Although the effect of these compounds on human beings is still under debate, their presence called for caution regarding their chemical perseverance, microbial resistance, and synergistic effects. The degradation and removal of PPCPs/EDCs in aqueous solution therefore requires different techniques which are very diverse. Different destructive methods that allow the efficient elimination of the pollutants from an aqueous form could be chosen. But recent reports suggested that more than one treatment technique may be required to degrade these compounds, depending on the nature of target compounds. The risk posed by these emerging micropollutants on humans and the environment requires further investigation. Therefore, it becomes imperative to improve on the existing techniques used to remove and degrade these chemicals in the natural ecosystems, most essentially in drinking water, as fast as possible. To date, a review of the related literature indicated that there is little or no information regarding the use of combined advanced oxidation processes to remove pharmaceuticals and endocrine disrupting compounds from aqueous solutions.

\section{Pharmaceutical and Personal Care Products}

Pharmaceuticals are any synthesized chemicals compounds or drugs designed to cure and prevent the spread of diseases as well as adding value to humans and animals life (Maletz et al. 2013) while personal care products encompasses cosmetics, fragrances, preservatives, and toiletries (Houtman 2010). Pharmaceuticals include antibiotics, anti-diabetics, anti-epileptic, antimicrobials, anti-anxiety medications, etc. Personal care product includes shampoos, toiletries, toothpaste, perfume, deodorants, etc. Pharmaceutical and personal care products (PPCPs) are chemical compounds that have been the subject of discussion among scientists and the general public especially in the developed countries such as China, USA, Germany, and European Union since the early 1990s (Ternes et al. 2004; Ternes and Joss 2006). Their presence in the environment poses a great threat to public health and impacts negatively on the aquatic ecosystem. One of the potential sources of the lingering PPCPs in the aquatic environment is through the discharge of inadequately treated wastewater (Daughton and Ternes 1999; Ternes et al. 2002; Fawell and Ong 2012). Due to the partial elimination of these pollutants by wastewater treatment plants, many of the contaminants survive and escape from the sewage treatment plants into surface water. Some were however retained and adsorbed onto sewage sludge. The sludge which is sometimes used by farmers for agricultural soil enrichment also contains emerging pollutants and thus represents another way these contaminants get into soil and water. Apart from this, the partially metabolized drugs as well as medical care products either in original or altered form are equally released into wastewater and later find their way to and through the treatment

\section{http://repository.uwc.ac.za}


plants. In spite of the municipal wastewater treatment plants being the most widely known source where many of PPCPs and EDCs are released, researchers have also discovered the presence of hundreds of EDCs and PPCPs in seawater. This development was ascribed to the flow of wastewater effluents by river into various larger water bodies such as the ocean (Liu et al. 2010; Joseph et al. 2011). This trend was supported by Richardson and Ternes (2005) who observed that more PPCPs exist in the aquatic environment as a result of the increasing number of expired drugs presently being discarded in the medical field. The resultant harmful effects of some PPCPs are poorly known, bearing in mind they are persistent and bioactive, and bioaccumulate in the aquatic environment. PPCPs also comprise synthetic hormones, fragrances, shampoos, detergents, analgesics and their metabolites, etc. Some of these get introduced into water through industrial and household discharge. Although PPCP concentration in the environmental samples is quite low, questions were raised regarding their microbial resistance, chemical persistence, and the synergistic effects of various compounds (Daughton and Ternes 1999). However, the vast majority of people are still ignorant or not aware of the health risk associated with exposure to these chemicals. This was evidenced in the survey carried out in United States of America where people carelessly disposed expired and unused medicines into sinks and toilets instead of returning it to pharmacies (Petrovic et al. 2004). Several studies have shown that over 140 PPCPs of different recommended classes were detected in different countries (Halling-Sørensen et al. 1998; Daughton and Ternes 1999; Kümmerer and Al-Ahmad 2010; Heberer 2002; Janex-Habibi et al. 2004; Larsen et al. 2004; Garric and Ferrari 2005; Fent et al. 2006). Some of these reports substantiate the concentration range values as well as removal rate of PPCPs by the various treatment plants. Quite a large proportion of PPCPs have been acknowledged to exist and persist in underground, surface, and drinking water as well as municipal sewage sludge across the globe at low concentrations (Kim et al. 2007; Focazio et al. 2008; Kinney et al. 2008; Fick et al. 2009; Benotti et al. 2009; Wu et al. 2009; McClellan and Halden 2010). This problem has been known for more than a decade, yet little progress has been made to stem the tide of such pollutants from entering the global waterways. Information on selected representative classes of PPCPs and EDCs most frequently found and detected in surface waters, wastewater, and sewage treatment plants is shown in Table 1. Some of the PPCPs and EDCs such as bisphenol A, pesticides (e.g., 2, 2,- bisp-chlorophenyl-1-1-1-trichloroethane, atrazine), organohalogens (such as furans, brominated fire retardants, dioxins) phthalates, polychlorinated biphenyls (PCBs), and polycyclic aromatichydrocarbons are more frequently found in wastewater treatment plants than in natural environment. 
Table 1 Some representative classes of EDCs and PPCPs reported in surface waters, wastewater, and sewage treatment plants

\begin{tabular}{|c|c|c|}
\hline EDCs/PPCPs class & Compound detected & Use/origin \\
\hline Phthalates & $\begin{array}{l}\text { Butylbenzylphthalate, di-(2-ethylhexyl) } \\
\text { phthalate, and di- } n \text {-butylphthalate }\end{array}$ & $\begin{array}{l}\text { They are found in detergents, resins, } \\
\text { some addictives, and monomers used } \\
\text { in the production of plastics }\end{array}$ \\
\hline Pesticides & $\begin{array}{l}\text { 2,2-bis-p-Chlorophenyl-1,1-dichloroethylene } \\
\text { (DDE), 2,2-bis-p-chloro-phenyl-1,1,1- } \\
\text { trichloroethane(DDT), deltamethrin, } \\
\text { carbofuran, atrazine, lindane, vinclozolin, } \\
\text { carbendazim, and tributylin }\end{array}$ & $\begin{array}{l}\text { Extensively used in agriculture. Insecticides, } \\
\text { herbicides, and fungicides are included in } \\
\text { this class }\end{array}$ \\
\hline Organotin compounds & Tributyltin and triphenyltin & Compounds used in antifouling paints on ships \\
\hline Alkylphenols (surfactants) & $\begin{array}{l}\text { Nonylphenol, nonylphenol etoxylate, } \\
\text { octylphenol, octylphenol etoxylate }\end{array}$ & $\begin{array}{l}\text { They are used during the production of phenol } \\
\text { resins, as plastic additives, emulsifiers, in } \\
\text { agricultural and industrial applications }\end{array}$ \\
\hline Bisphenols & Bisphenol A & $\begin{array}{l}\text { Bisphenol } \mathrm{A} \text { is used in the manufacture of } \\
\text { polymers (polycarbonates and epoxy resins), } \\
\text { flame retardants and rubber chemicals }\end{array}$ \\
\hline Pharmaceuticals (synthetic steroids) & Diethylstilbestrol and 17-ethinylestradiol & $\begin{array}{l}\text { Synthetic steroids mainly consist of oral } \\
\text { contraceptives as well as steroids used for } \\
\text { substitution therapy during menopause }\end{array}$ \\
\hline Natural hormones & Estrone, 17-estradiol & $\begin{array}{l}\text { Estrogens naturally and daily excreted in human } \\
\text { urine and animals }\end{array}$ \\
\hline Analgesics/non-steroidal & $\begin{array}{l}\text { Acetaminophen (analgesic), diclofenac, } \\
\text { ibuprofen }\end{array}$ & $\begin{array}{l}\text { NSAIDs are the most used and abused drugs in } \\
\text { the world today }\end{array}$ \\
\hline Anti-inflammatories (NSAIDs) & $\begin{array}{l}\text { Ketoprofen, naproxen, phenazone, } \\
\text { indomethacine }\end{array}$ & $\begin{array}{l}\text { All NSAIDs have analgesic, antipyretic and } \\
\text { anti-inflammatory effect }\end{array}$ \\
\hline Antiseptics & Triclosan and thymol & $\begin{array}{l}\text { Antiseptics are chemical agents that slow or stop } \\
\text { the growth of microorganisms (germs) on } \\
\text { external surfaces of the body and help prevent } \\
\text { infections. Antiseptics should be distinguished } \\
\text { from antibiotics that destroy microorganisms } \\
\text { inside the body and from disinfectants, which } \\
\text { destroy microorganisms found on inanimate } \\
\text { (non-living) objects }\end{array}$ \\
\hline Antibiotics/antimicrobials & $\begin{array}{l}\text { Sulfonamides, fluoroquinolones, } \\
\text { trimetoprim, chlortetracycline, } \\
\text { erythromycin, lincomycin, } \\
\text { oxytetracycline, tetracycline, } \\
\text { roxithromycin, tylosin }\end{array}$ & $\begin{array}{l}\text { Used for the treatment of bacterial infections in } \\
\text { both humans and animals }\end{array}$ \\
\hline Antiepileptics & Carbamazepine & $\begin{array}{l}\text { Antiepileptics are commonly used in medicine } \\
\text { to stop, prevent or control seizures } \\
\text { (convulsions, partial seizures, generalized } \\
\text { tonic-clonic seizures, etc.) }\end{array}$ \\
\hline Anti-anxiety/hypnotic agents & Diazepam & $\begin{array}{l}\text { Anti-anxiety/hypnotic agents are used to relieve } \\
\text { anxiety, nervousness, and tension associated } \\
\text { with anxiety disorders }\end{array}$ \\
\hline Lipid regulators & Clofibrate, bezafibrate & $\begin{array}{l}\text { Lipid regulators may be used to lower cholesterol } \\
\text { and triglyceride (fat-like substances) levels in } \\
\text { the blood }\end{array}$ \\
\hline
\end{tabular}

Sources: Adopted from Esplugas et al. (2007)

Others such as nonylphenol and octylphenol are more prominent in surface and groundwater (Esplugas et al. 2007). These chemicals compounds have been established to disrupt endocrine systems, yet they are still unregulated and discharge carelessly into the immediate environment most especially in the developing countries where there is no stringent regulatory and legal frame work.

\section{http://repository.uwc.ac.za}




\subsection{Sources of Pharmaceuticals, Personal Care Products, and Endocrine Disruptors}

The frequency of drugs and medical care products use has continued to increase as a consequence of the population growth rate and as such a large quantity of different byproducts is continuously being released into the environment, although at low concentrations (Kolpin et al. 2002; Yu and Chu 2009). This concentration level varies from country to country depending on the drug consumption, usage pattern, population index, and treatment plant potential (Bolong et al. 2009). For instance, the concentration of bisphenol A in North American and European water is around 12 and 43 ppb, respectively (Klecka et al. 2009; Rogers et al. 2013). Ellis (2006) and Czech and Rubinowska (2013) asserted that an average of 170 pharmaceuticals in excess of 1 ton per year were projected to be used in Brussels. The presence of these contaminants of emerging concern has been observed to seriously affect the water quality and obviously attract attention with regard to drinking water issues (Heberer 2002; Trussell 2001; Yu and Chu 2009). The structural complexity of the compounds was ascribed to their physical and chemical properties which have contributed greatly to their prevalent distribution into the environment (Rosal et al. 2010). Presently, most of the wastewater treatment plants are not designed to effectively treat emerging contaminants. Because of this, a high proportion of their metabolites escape and get introduced to aquatic environment as effluents. This occurs through physical and chemical breakdown, during disposal and recycling operations within wastewater treatment plants (WWTPs). Numerous studies supported this claims that wastewater treatment plants and untreated urban wastewater acted are the major routes through which PPCPs and EDCs get released into various water sources (Barnes et al. 2002; Pryor et al. 2002; Harrison et al. 2006). Subsequently, due to their hydrophobic nature, PPCPs and EDCs in water associated with particulate matter and hence settle at the bottom sediments and accumulated continuously through electrostatic interaction. Apart from WWTP discharges, other sources includes animal feeding operations, land-applied bio-solids, row-crop production, on-site wastewater disposal systems, recreational activities, transportation or wash-off from roadways, and atmospheric deposition (Kidd et al. 2007; Bonefeld-Jorgensen et al. 2007; Palace et al. 2009; Sellin et al. 2009; Rogers et al. 2013). In the same vein, PPCPs and EDCs come into the aquatic environment through the discharge of residual chemicals by householders and by agronomy and manufacturing industries (Fig. 1) (Boyd et al. 2003; Bonefeld-Jorgensen et al. 2007; Besse et al. 2008; Besse and Garric 2009; Sellin et al. 2009; Kümmerer and AlAhmad 2010; Vulliet and Cren-Olivé 2011; Brausch and Rand 2011; Besse et al. 2012; Qin et al. 2012). Houeto et al. (2012) affirmed the presence of metabolized and partially metabolized drug residues in various water sources such as wastewater, groundwater, surface water, and drinking water. Accidental spills could also be other sources of PPCPs and EDCs in the aquatic ecosystems (Falconer et al. 2006; Huang et al. 2008). Personal care products enter into the aquatic environments through recreational activities such as swimming and also through showering and bathing as well as other technological process (Larsson et al. 2007). According to Brooks et al. (2006), the accidental ejection of PPCPs and EDCs effluent to ecosystems were responsible for some of the worstscenario waterborne diseases that impacted negatively on human health. Boxall et al.

\section{http://repository.uwc.ac.za}


(2004) also noted that livestock faeces, residual animal medicine, and aquaculture uses are also other routes through which PPCPs and EDCs are being released into the environment. Some PPCPs and EDCs enter into the groundwater through leaching and leaking of poorly designed sewer and landfills (Fawell and Ong 2012). In a related development, Jackson and Sutton (2008)) detected that local sources such as poor sanitary sewer systems at different residences, commercial, and industrial locations in California contained a high concentration of contaminants such as phthalates, triclosan, and BPA. Jackson and Sutton (2008) in their pilot study carried out established the presence of synthetic endocrine-disruptors such as phthalates, bisphenol A, and triclosan in the surface waters in Oakland, USA. The authors linked the occurrence of the pollutants to the leakage of sanitary sewer system. According to Writer et al. (2010), the occurrence of bisphenol A, 17ßestradiol, estrone, and 4-nonylphenol in 11 selected lakes in Minnesota, USA, was ascribed to land-use activities and lake tropic conditions but not wastewater treatment plants.

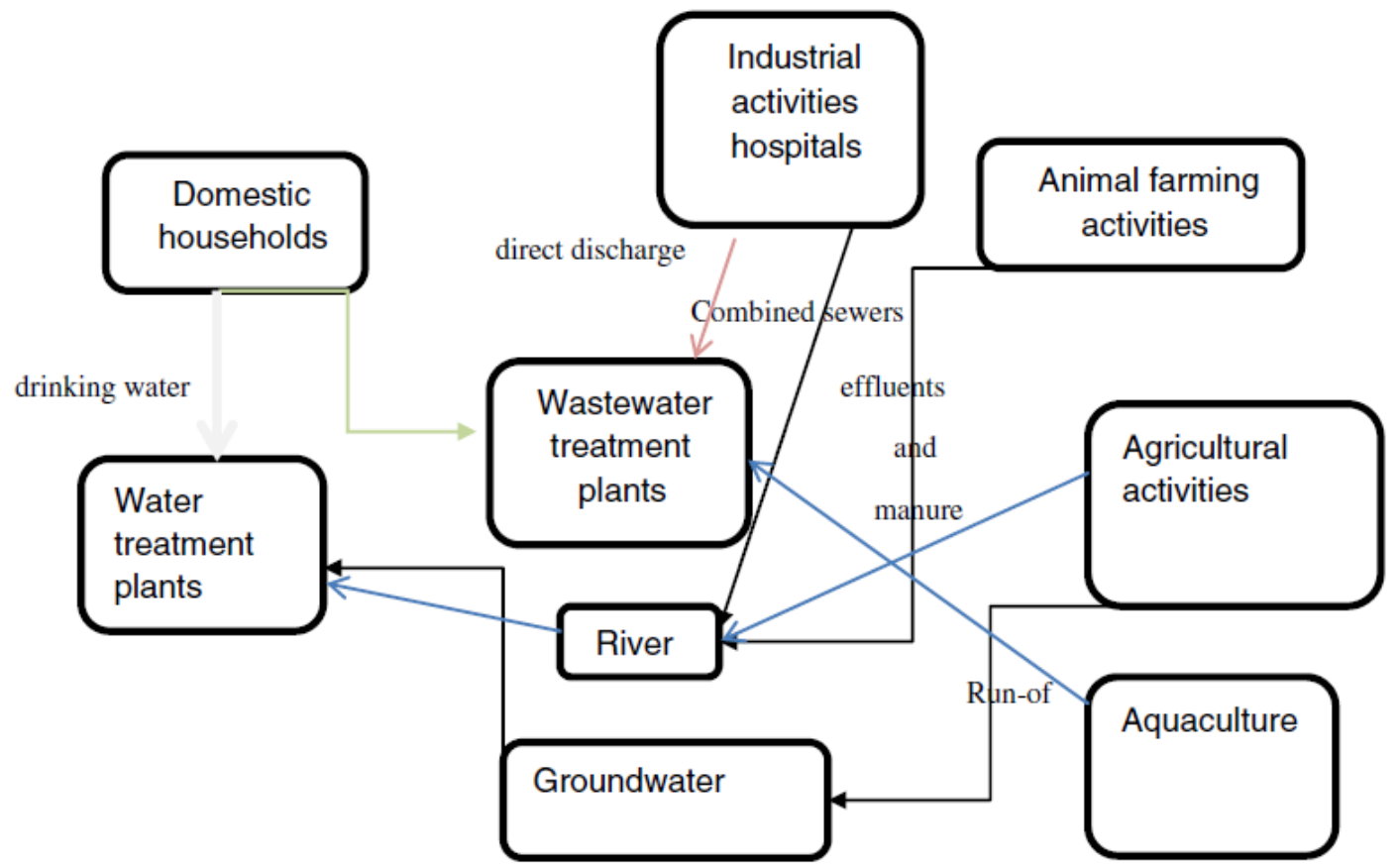

Fig. 1 Possible sources and routes of PPCPs/EDCs in water cycle (Petrovic et al. 2003)

The authors confirmed that the sources of endocrine disruptors are wide spread and diverse in nature. In Europe and North America, the occurrence of PPCPs and EDCs in rivers and lakes were attributed to poor agricultural practices and sewage effluent. Maletz et al. (2013) identified municipal sewage treatment plants, livestock breeding, and hospital effluents as the main point sources through which EDCs are introduced into aquatic environment.

In emerging and underdeveloped nations such as those in Africa and Asia, careless refuse dumping and untreated industrial effluent discharge into waterways are very common. This also contributes to the high level of PPCPs and EDCs in aquatic ecosystems (Olujimi et al. 2010). The discharge and exposure to small concentration of PPCPs and EDCs were

\section{http://repository.uwc.ac.za}


reported to be allied with endocrine gland malfunction, chronic toxicity, and pathogen resistance (Rosal et al. 2010). The coverage pattern of PPCPs and EDCs manufactured for human and animal also differs. The human PPCPs and EDCs behave as pseudo-persistent when the effluents were discharged into aquatic systems despite their short environmental half-life and are likely to go back into the urban water cycle (Daughton 2002, 2004; Ankley et al. 2007) while animal drugs are transported to surface waters during rainfall or discharged openly in a single quantity to aquatic systems. Some of the PPCPs and EDCs later find their way into receiving water systems (Boyd et al. 2003; Barnhoorn et al. 2004; Carballa et al. 2004). For instance, in China, municipal wastewater discharge was identified as the major contributor of EDCs and PPCPs to riverine water (Peng et al. 2008). Also, more than 80 PPCPs and EDCs that were detected according to Heberer (2002) originated from reclaimed water used for artificial groundwater recharge. Kolpin et al. (2002) in his study established that close to 80 \% of 139 streams in US were contaminated with antimicrobial agents, fire retardants, steroidal hormones, as well as emerging pollutants. Thus, the growing re-use of reclaimed domestic wastewaters for irrigation could also be central in low-level PPCPs escaping into urban storm water runoff from the irrigated area. Also, Dean (2007) and Lyons (2008) reported independently that once the emerging micropollutants are released into the environment their harmful effects on the local ecosystems and human residents are unlimited. Yu and Chu (2009) attributed the wide occurrence of some PPCPs and EDCs such as ibuprofen, bisphenol A, caffeine, triclosan, and bis (2-ethylhexyl) phthalate along the West Prong Little Pigeon River, in the USA, to the wastewater discharge into the river. Ortiz de García et al. (2013) linked the presence of PPCPs and EDCs in the natural environment to many factors among which were the consumption patterns and water use as well as the peculiarity of the wastewater treatment plants. Jin et al. (2004) reported that there have been reports of high concentrations of bisphenol A (BPA) in the rivers and marine environments in China, although the assessment of BPA has not been extensive especially in terms of monitoring data for drinking water. Peng et al. (2008) observed wide occurrence of 19 endocrine disrupting pharmaceuticals in urban riverine water of the Pearl River Delta, South China. The concentrations of the micropollutants after analysis were discovered to be high. The authors ascribed the large presence of pharmaceutically active compounds in the river to careless refuse dump and municipal wastewater discharge.

\subsection{Environmental Fate and Behavior of PPCPs and EDCs}

Most PPCPs and EDCs are polar and highly hydrophilic with low partition coefficient (Kow) and partially soluble in aqueous media. Their presence and bioavailability in the aquatic environment depends on the interactions between solids and water in sludge and sediment. In some cases, some PPCPs and EDCs concentration in the water was higher. This is as a result of series of phase transformations processes involving biodegradation, dilution, and photolysis in water environment whereas, in other cases, persistent organic pollutants, such as polyaromatic hydrocarbon, or organochlorine pesticides bioaccummulate and get adsorbed by the sludge. By and large, it could be inferred that the hydrophobicity of a chemical substance will determine whether PPCPs or EDCs will bioaccumulate in the solid phase or not (Caliman and Gavrilescu 2009). The more

\section{http://repository.uwc.ac.za}


hydrophilic a pollutant is, the higher the tendency of being in the aqueous phase. Therefore, one of the most important parameters to be considered for chemical loss during adsorption onto sludge is the organic carbon normalized sorption coefficient (KOC). The chemical partitioning behavior of PPCPs and EDCs in aqueous media also depends on the partition coefficient $\left(\mathrm{K}_{\mathrm{OW}}\right)$. Hence, the greater the values are for both parameters, the more those compounds sorb upon organic carbons such as suspended solids, non-polar fats, lipids, and mineral oils whereas leaching of PPCPs from the soil or sediment may be attributed to low level of $\mathrm{KOC}$ and $\mathrm{K}_{\mathrm{OW}}$. The listed mathematical expression may be adopted as reference criteria to know if PPCPs or EDCs will be sorbed onto sediment or sludge.

(1) if Log KOW $<2.5$, then it signifies low sorption potential;

(2) if $2.5<\log \mathrm{K}_{\mathrm{OW}}<4.0$, it means medium sorption potential;

(3) Log KOW >4.0 may be equivalent to high sorption ability (Jones-Lepp and Stevens 2007;

Caliman an d G av rilesc u 2009 ). Ther efo $r$ e, the environmental distribution, bioavailability, reactivity, transport phenomenon, and toxicity potential of PPCPs and EDCs in natural and artificial ecosystem depends largely on the hydrophilicity and hydrophobicity sorption coefficient value of the contaminants (Suarez et al. 2008). Some indicative parameters such as estrogenic activity potency (relative to estradiol), environmental concentration, half-life, sorption $\mathrm{K}_{\mathrm{Oc}}$ for the environmental fate, and behavior of several EDCs and PPCPs are shown in Table 2, which lists some information concerning the environmental fate as well as the effects of EDCs and PPCPs.

\subsection{Effects of Pharmaceutical and Personal Care Products}

Many nations in the world today are highly concerned about the impending environmental crisis and substantial risk occassioned by the occurrence of PPCPs in the environment (Bound and Voulvoulis 2005; Glassmeyer et al. 2005; Heberer and Feldman 2005; Lishman et al. 2006; Larsson et al. 2007). Although many drugs are fashioned to respond to quite a large range of health challenges at low physiological doses (milligrams per kilogram), some are more dynamic and can perform best at nanograms-per-kilogram concentrations. After accomplishing the specific functions in the body, some still interact even at low quantity with multiple non-therapeutic receptors over the long-term, resulting in potentially harmful effects on non-targeted receptors in both aquatic and terrestrial wildlife. Strauch (2011) asserted that the effects of PPCPS on human toxicity irrespective of their concentration in the water supply are yet to be ascertained. Research conducted by Ternes et al. (2004) and Topp et al. (2008)) discovered that certain PPCPs, such as estrogenic compounds, have a very high bioaccumulation potential.

\section{http://repository.uwc.ac.za}


Table 2 Properties and processes that govern the fate of endocrine disruptor PPCPs in the environment

\begin{tabular}{|c|c|c|}
\hline Process & Property & Types of EDCs/environmental fate/effects \\
\hline \multirow[t]{4}{*}{ Chemical } & Solubility & Ionic, water-soluble ECDs; increased transport and dispersion/dilution \\
\hline & Volatility & $\begin{array}{l}\text { Some pesticides and industrial EDCs; global redistribution by evaporation and } \\
\text { atmospheric transport }\end{array}$ \\
\hline & Stability & $\begin{array}{l}\text { Many organic halogenated compounds; persistence } \\
\text { in the environment }\end{array}$ \\
\hline & Partitioning & $\begin{array}{l}\text { Non-polar EDCs that bind to solids and lipids; partition into soil/sediment } \\
\text { and biota (solid/liquid/gas) }\end{array}$ \\
\hline \multirow[t]{5}{*}{ Environmental } & $\mathrm{pH}$ & Affects ionic EDCs, e.g., phenolics, and cellular reaction media \\
\hline & Salinity & Osmoregulation; affects also fate of ionic species in coast gradients \\
\hline & Temperature & Governs reactions; extremes (cold) increase stress; adapted hormonal functions \\
\hline & Photoperiodicity & Marked effects on many hormonal cycles (diurnal, lunar, annual) \\
\hline & Humus content & Binder, carrier, reaction site, etc. \\
\hline \multirow{6}{*}{$\begin{array}{l}\text { Retention and } \\
\text { transport }\end{array}$} & Sorption & On humus/minerals; on aerosol particles; on plants and other biological tissues \\
\hline & Precipitation & In sorbing particles or as salts; dynamic equilibria with resuspension \\
\hline & Complexation & With other ligands e.g., in humus \\
\hline & Colloid formation & With humus; may enhance transport of, e. g., heavy metals in soil \\
\hline & Advection/dispersion & In free air, surface water, ground water (porous soil) \\
\hline & Diffusion & Impermeable soils; slow but may be important overall \\
\hline \multirow[t]{5}{*}{ Transformation } & Active transport & By humans/animals \\
\hline & Acid dissolution & Of polar EDCs in particular \\
\hline & Hydroxylation & Important for many persistent organics, e.g., PCBs \\
\hline & Chemical adducts & Important for many persistent organics, e.g., PCBs \\
\hline & Degradation/biotic & Depends on molecular structure and environment (humidity, $\mathrm{pH}$, nutrients, redox) \\
\hline \multirow[t]{4}{*}{ Accumulation } & Degradation/abiotic & Photo-decay in atmosphere and surface water \\
\hline & Polymerization & For some EDCs/conditions \\
\hline & Bioaccumulation & Bio-accumulating EDCs in food-chains; in tissues (lipid, bone) \\
\hline & Other accumulation & In (deep non-turbulent) sediments and soils \\
\hline
\end{tabular}

Sources: (Assmuth and Louekari 2001; Caliman and Gavrilescu 2009)

This environmental bioaccumulation exacerbates the abnormal hormonal control causing reproductive impairments, decreased fecundity, increased incidence of breast and testosterone cancers, and persistent antibiotic resistance. This severe, eco-toxic, and prolonged toxicity experienced due to the presence of PPCPs in the environment is similar to that of health effects caused by the presence of metallic elements detected at concentration below $1 \mathrm{mg} / \mathrm{L}$ in which the endocrine system are grossly affected (Sharpe and Irvine 2004; Xia et al. 2005; Bisceglia and Roberts 2006). Lear et al. (2002) and Hileman (2005) both submitted that contamination by certain PPCPs, especially antibiotics, at trace level in water equally contribute to the widespread impact and frequent occurrence of antibacterial resistance. This rise in antibacterial resistance has overstretched the medical costs of communities due to re-occurrence of hospitalization as well increased treatment cost. This is even worse in the developing countries where income per day is mostly less than 1 US dollar. Lin et al. (2008) revealed that certain fractions of partially metabolized drugs were found in waste stream, animal waste, and pharmaceutical effluents, and some of these drugs later undergo various degrees of transformation in the aqueous media.

\section{http://repository.uwc.ac.za}


During this period, entirely new products that differ with diverse ecotoxicological activity from the starting material are formed. The main characteristic property and processes linked to the occurrence and fate of the endocrine-disrupting pharmaceuticals are summarized in Table 2 below. The fate and behavior of these emerging micropollutants are quite diverse and complex depending on the environmental factors. The knowledge on the environmental fate of EDCs and PPCPs are still limited.

\section{Endocrine-Disrupting Compounds}

Some compounds do obstruct or mimic or antagonize the endocrine system, and these substances are known as endocrine-disrupting chemicals. Endocrine systems control a quite a large number of body physiological activities such as reproductive processes like embryonic development, sex differentiation, and metabolic development (Flint et al. 2012). Endocrine-disrupting compounds may block the hormonal growth in the endocrine system and affect the physiological activities of endogenous hormones (Schug et al. 2011). They are alternatively called environmental hormones that cause adverse effects on aquatic and terrestrial organisms through altering the metabolism of natural hormones, modifying hormones receptor in a cell, interference, or binding to receptors of the endocrine system (Jiao and Cheng 2008; Olujimi et al. 2010). EDCs can be natural or man-made. Others include alkyl-phenols, dioxins, various drugs, synthetic birth control pills, pesticides, plasticizers, and phenolic products (Jackson and Sutton 2008). The exposure of humans to endocrine disruptors in recent years has received increased attention due to the high exposure rate especially among the aquatic organisms. Ever since, there has been increasing concern with regard to the likely impacts of exposure to chemical compounds with endocrine-disrupting activity in the environment (Segner 2005; Sumpter 2005; Game et al. 2006; Mauricio et al. 2006; Xue and Xu 2006; Moder et al. 2007; Shin et al. 2007; Hecker and Giesy 2008). In addition, high tendencies of multiplicative and evolving abnormalities in infants and children, temporal descending trends in semen quality and testosterone levels, and worldwide increased rates of testicular and thyroid cancers among adult male populations have been attributed to EDCs exposure (Swan et al. 2000; Huyghe et al. 2003; Davies and Welch 2006; Travison et al. 2007; Andersson et al. 2007). These reported health cases alerted the scientific and public communities regarding the potential risk of environmental EDCs to men's health. Although the effect of EDCs on human health and wildlife biology were first documented in the 1930s, the real research progressed in the late 1970s and early 1980s (Vogel 2004; Trenholm et al. 2006; Moder et al. 2007). Human beings exposure to EDCs could be through dermal absorption or contaminated media such as water, food, air, and soil. To date, no comprehensive list of EDCs exists, because most of the new chemicals are being manufactured continuously. There is a very limited and incomplete evidence of endocrine-disrupting activity because more than 87,000 new chemicals in the market have not been tested for their endocrine toxicity (Snyder et al. 2006; Kim et al. 2007). Presently, more than 38,000 chemicals and potentially toxic elements have been identified as potential endocrine-disrupting pharmaceuticals. This is an indication that more chemicals may be recognized as endocrine disrupters as the sum of compounds surges with unanticipated effects (Ferraz et al. 2007; Fatoki and O peolu 20 09). This will require identification and elimination of these

\section{http://repository.uwc.ac.za}


compounds from the water system. Yet again, this well-documented knowledge of the hazards has yet to trigger an adequate precautionary principle approach to control and monitoring new compounds before their release into market place and from there into the receiving environment.

\subsection{Effects of Endocrine-Disrupting Compounds}

The available proof from the relevant literature associated the abnormalities and health challenges experienced by aquatic organisms with exposure to low concentration of EDCs (nanograms per liter). The toxic impacts of EDCs on the ecosystem have continued to be the subject of research and published data in the scientific and public health communities over the last 20 years due to the mimicking or disrupting potential of the endocrine system (Murray et al. 2001; Thorpe et al. 2003). The effects of these emerging micropollutants upon animals are well reported (Table 3), although earlier studies stated that there have not been primary effects upon humans and recommended further study (Harrison 2001; Sharpe and Irvine 2004). Many synthetic chemicals such as pesticides, BPA, and phthalate plasticizers, and indeed estrogens and subordinate plant metabolites have been observed to possess endocrine-disrupting properties ( $\mathrm{Naz} 2005$ ). Most of these EDCs bind to the cell receptor and antagonize the endocrine glands responsible for hormonal secretion. Subsequently, they block the various mechanistic signals of the endocrine system and hence modify the hormonal receptor cells (Olujimi et al. 2010). Some of the potential endocrine-disrupting PPCPs are shown in Fig. 2.

There are diverse opinions on the effects of EDCs on wildlife and humans; some researchers are of the view that there is a link between exposure and effects of EDCs in animals and humans while some disputed the claims ( $\mathrm{Xu}$ et al. 2008). However, studies by Michael (2001) discovered that exposure to EDCs have consequential health effects on many aquatic species which includes a low sperm count, increasing ovarian, prostate, testicular, breast cancer, diabetes/metabolic syndrome, and reproductive failures. These effects of EDCs on the natural ecosystem depend on the lipophilicity increase, exposure time, and biotransformation mechanism. However, some EDCs fail to degrade directly, but instead were metabolized into other by-products, even more toxic than the original chemicals, thereby increasing their effects on the ecosystem. Information on the aquatic organisms affected by exposure to EDCs and PPCPs are shown in Table 3. Human beings and aquatic organisms get exposed to PPCPs or EDCs through water, food, soil, or dermal adsorption (Olujimi et al. 2010). Burkhardt-Holm et al. (2005) and Kidd et al. (2007) attributed the declining rate of fish in freshwater systems to the widespread presence of estrogenic chemicals. Safe (2000) also perceived that exposure of aquatic organisms to organochlorines led to feminizations of fishes and gulls, and sexual irregularities in alligators. In addition, there are increasing occurrences of reproductive and developmental abnormalities among infants and children, pregnancy loss, birth defects, growth retardation, ovarian failure, low semen quality, and increased rates of testicular and thyroid cancers (Swan et al. 2000; Huyghe et al. 2003; Davies and Welch 2006; Travison et al. 2007; Andersson et al. 2007; Enewold et al. 2009). These deficiencies occurred as a result of exposure to EDCs through oral ingestion such as breast milk, infant formula,

\section{http://repository.uwc.ac.za}


contaminated water, food, surface, and carpet dust (Olujimi et al. 2010). This has generated concern regarding the potential risk of environmental EDCs to men's health. Mackenzie et al. (2005) and Safe (2000) ascribed the decline in sex ratios in Canada and the United States to over exposure to EDCs. With the recently reported cases of adverse health implication due to exposure to EDCs, the development of highly efficient technology is necessary in order to maintain public health and ecosystem stability (Lee et al. 2003; Braga et al. 2005).

\section{Removal of Pharmaceuticals and Endocrine-Disrupting Compounds-An Overview}

Despite appropriate legislation framework especially in the advanced nations to check inflow of endocrine disruptors and pharmaceuticals into drinking water, the problem still persist (Focazio et al. 2008; Swati et al. 2008; Rahman et al. 2009a, b). Efforts were made and still ongoing to check mate this ugly trend towards removing or degrading the persistent refractory pharmaceuticals and endocrine-disrupting compounds in water and wastewater.

Table 3 Some endocrine-disrupting chemicals, hormone target, and animals affected

\begin{tabular}{|c|c|c|c|}
\hline Compounds & Common usage & Interference hormone & Animals affected \\
\hline Bisphenol A & Plasticiser & Thyroxine, cortisol & Mammals, birds, fish \\
\hline $\begin{array}{l}\text { Butylbenzyl phthalate (BBP), } \\
\text { di(2-ethylhexyl) phthalate (DEHP), } \\
\text { di-n-butylphthalate ( D-n-BP) }\end{array}$ & Plasticiser & Estrogens & $\begin{array}{l}\text { Mammals, birds, fish, } \\
\text { reptiles, amphibians }\end{array}$ \\
\hline $\begin{array}{l}\text { Polychlorinated biphenyl (PCBs), } \\
\text { dioxins, pentachlorophenol (PCP), } \\
\text { polychlorinated dibenzofurans (PCDFs) }\end{array}$ & $\begin{array}{l}\text { Flame retardants, unintended } \\
\text { by-products during } \\
\text { incineration }\end{array}$ & Estrogens & Reptiles, amphibians \\
\hline p-Nonylphenol & Plasticiser & Estrogens & $\begin{array}{l}\text { Mammals, birds, fish, } \\
\text { reptiles, amphibians }\end{array}$ \\
\hline $\begin{array}{l}\text { 2,2-bis-p-chloro-phenyl-1,1,1-trichloroethane } \\
\text { (DDT), 2,2-bis-p-chlorophenyl-1, } \\
\text { 1-dichloroethylene (DDE), DDE, chlordane } \\
\text { dieldrin, heptachloro, lindane, } \\
\text { endosulfan, oxychlordane, etc. }\end{array}$ & Insecticides & Estrogens and androgens & $\begin{array}{l}\text { Mammals, birds, fish, } \\
\text { reptiles, amphibians }\end{array}$ \\
\hline
\end{tabular}

Sources: (Hill et al. 2001; Zala and Penn 2004; Olujimi et al. 2010) 


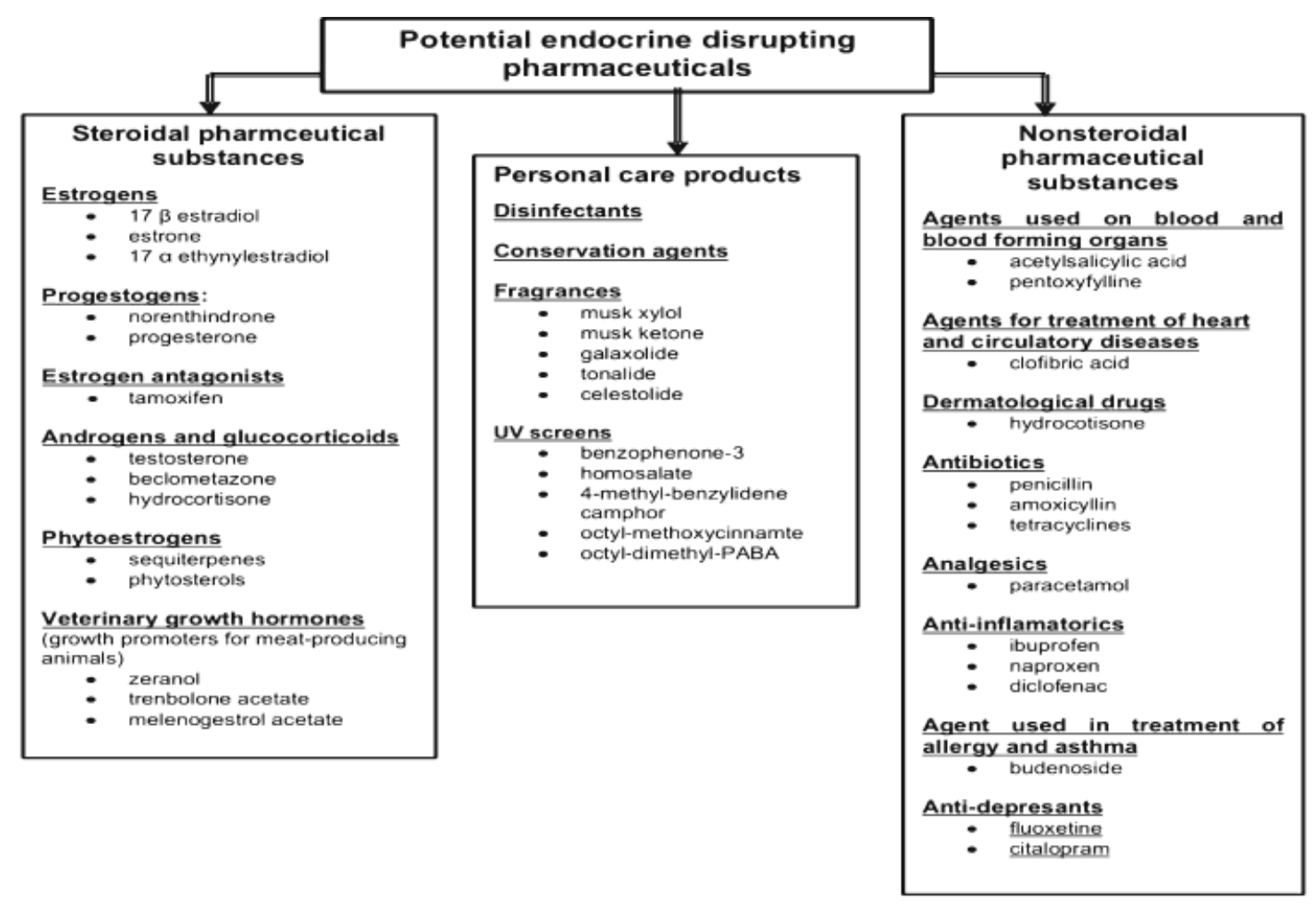

Fig. 2 Scheme of the potential endocrine disruption PPCPs (Source: Caliman and Gaurilescu 2009)

A number of the conventional wastewater treatment technologies have so far been reported in the literature. However, these technologies are not without defects in the removal of pharmaceuticals and endocrine disruptors from contaminated water. For instance, physicochemical treatment such as activated carbon adsorption (Nowotny et al. 2007; Snyder et al. 2007; Yu et al. 2008), reverse osmosis, nanofiltration and (Snyder et al. 2007) and coagulation-flocculation, and membrane filtration (Snyder et al. 2007; Yoon et al. 2007) were discovered not to perfectly remove EDCs and PPCPs. Instead, they end up generating other toxic by-products. Nevertheless, an appreciable success was recorded when biological and physical treatments were combined, including less generation of byproducts (Zhang et al. 2010). This was evidenced in the study conducted by Al-Rifai et al. (2011) when combined activated sludge, microfiltration, and reverse osmosis were used to remove 11 pharmaceuticals and two endocrine disruptors in a water recycling process. The authors established $97 \%$ removal rate when water concentration was below $0.1 \mu \mathrm{g} / \mathrm{L}$ f or most compounds except bisphenol A with concentration above $0.5 \mu \mathrm{g} / \mathrm{L}$. The authors concluded that the combined system did not only efficiently remove the micropollutants, but also succeeded in reducing the concentrations of some physicohemical parameters. Hence, in order to reduce their concentration to a less harmful level, a more sensitive and reliable technology is needed. To date, little or no extensive compilation of papers published on the use of combined techniques to degrade pharmaceuticals and endocrine-disrupting compounds from wastewater have been reviewed. Suffice to mention that most of the reported methods of removing emerging contaminants are categorized into three approaches according to Liu et al. (2009); these

\section{http://repository.uwc.ac.za}


include physical methods, biodegradation, and advanced oxidation processes. This review focused most importantly homogeneous and heterogeneous advanced oxidation processes.

\subsection{Advanced Oxidation Processes}

Advanced oxidation processes (AOPs) are very effective techniques capable of completely mineralizing the EDCs and PPCPs (Mendez-Arriaga et al. 2008). AOPs are chemical oxidation techniques encompassing organic pollutant removal and degradation under the influence of highly reactive hydroxyl radicals (Saien and Soleymani 2007; Saien and Khezrianjoo 2008; Saien et al. 2011). The hydroxyl radical is highly reactive and non-selective against refractory organic pollutants with subsequent conversion of the pollutants to $\mathrm{CO}_{2}, \mathrm{H}_{2} \mathrm{O}$, and mineral acids. In the last couple of years, AOPs have been extensively exploited and reported in the literature for the degradation of different wastewater containing contaminants such as pesticides, pharmaceuticals, endocrine disruptors, and dye molecules (Stasinakis 2008; Saien et al. 2011; Machulek Jr et al. 2013). AOPs could be generally classified into (1) homogeneous AOPs and (2) heterogeneous AOPs. The two categories are reviewed as follows:

Heterogeneous Advanced Oxidation Processes This is defined as a reaction process in which semiconductor catalyst dissociated under the influence of photon energy. In this case, the catalyst and the reactant exist in different phases. Among the heterogeneous advanced oxidation processes is the solid semiconductor $\mathrm{TiO}_{2}$ photocatalyst reviewed below.

\subsubsection{Heterogeneous Photocatalysis}

Semiconductor photocatalysis recently emerged technique as one of the advanced oxidation processes responsible for degrading recalcitrant, hazardous, and nonbiodegradable substances in wastewater and drinking water into relatively less risky products such as $\mathrm{CO}_{2}, \mathrm{H}_{2} \mathrm{O}$, and inorganic ions. Despite these useful functions, the postseparation of the used $\mathrm{TiO}_{2}$ photocatalysts from wastewater treatment remains a major challenge. Many efforts were geared towards addressing this problem, and such efforts included immobilization of $\mathrm{TiO}_{2}$ upon different supports such as silica, perlite, activated carbon, clay, zeolites, and many others (Yao et al. 2010). Most of these support materials are chosen because of their higher surface area. This is to guarantee highly active reaction centers as well as improved light penetration and reflection on the support pores (Friedmann et al. 2010; Czech and Rubinowska (2013). Several studies have considered the use of titania photocatalysts or the immobilized form of titania to degrade and mineralize organic compounds (Nakashima et al. 2003). Some of these are summarized as follows so as to give comparative data to the scholars in this area. Due to the enormous availability of treatment techniques for contaminants of emerging concern, it is not possible to review all, but the review will try to capture advanced oxidation techniques involving singular and combined photocatalytic degradation of emerging contaminants.

Chong and Jin (2012) explored the photocatalytic ability of a titanium dioxide $\left(\mathrm{TiO}_{2}\right)$ nanofiber as a pre-treatment technique to degrade carbamazepine using simulated

\section{http://repository.uwc.ac.za}


wastewater. The findings revealed that $78 \%$ of CBZ, $40 \%$ of chemical oxygen demand (COD) and $23 \%$ of $\mathrm{PO}_{4}$ concentrations from influent contaminated water were removed during the 4-h reaction time. After 0.5 -h treatment, the analysis by high-performance size exclusion chromatography (HPLC) revealed a dramatic shift of molecular weight from higher portion $(>10-1,000 \mathrm{kDa})$ to a lower level $(<10 \mathrm{kDa})$. Tsai et al. (2009) described the photocatalytic degradation of bisphenol A conducted using a $\mathrm{TiO}_{2}$ suspension reactor. The degradation capability was evaluated with respect to initial BPA concentration, $\mathrm{TiO}_{2}$ dosage, initial $\mathrm{pH}$, and temperature. The obtained first-order reaction constants (kobs) validated the degradation of BPA during the experiments. The photocatalytic degradation of diclofenac, metoprolol, estrone, and chloramphenicol was conducted in a tube reactor using different commercially available $\mathrm{TiO}_{2}$ by Czech and Rubinowska (2013). The prepared photocatalysts were characterized using BET, X-ray diffraction (XRD), and scanning electron microscopy (SEM), and it was observed that anatase $\mathrm{TiO}_{2}$ possessed the highest activity in the photocatalytic oxidation of diclofenac, chloramphenicol, and estrone whereas the presence of rutile only enhanced the photooxidation of metoprolol. The anatase $\mathrm{TiO}_{2}$ with $21 \mathrm{~nm}$ crystals was highly efficient for COD reduction in the treated water and the photooxidation of all studied pollutants followed pseudo-firstorder kinetics. The photocatalytic degradation of endosulphan and lindane (endocrinedisrupting compounds) in the presence of titania was also reported by Ashiya and Guatam (2011). The study revealed that the presence of acetone in the reaction mixture slowed the reaction competition for hydroxyl radicals between pesticides and acetone. The degradation efficiency of $95 \%$ (endosulphan) and $98 \%$ (lindane) coincided with the zero point charge of the catalyst at $\mathrm{pH}$ 7. Chong et al. (2011) opined that immobilized anatase titanate nanofiber and mesoporous $\mathrm{TiO}_{2}$ infused kaolinite catalysts in a photoreactor (SBASP) were responsible for the CBZ elimination from municipal wastewater. The experiment was investigated by varying the following parameters, batch reactor cycles, effluent organic matter, nitrate, and phosphate. The analyzed results as obtained from high-performance size exclusion chromatography revealed that the carbamazepine degradation was achieved.

Tables 4 and 5 below have highlighted clearly the difference between single techniques and combined treatment, in most cases, the combination approach appearing to be more promising in both organic pollutant elimination and degradation, as most combined treatment processes used were able to completely degrade and mineralize EDCs and PPCPs above $90 \%$. This makes the combined system for water reclamation a feasible substitute for commercialization in the nearby future.

In another study, photodegradation assisted by $\mathrm{TiO}_{2}$ was conducted for degrading estrone and $17 \beta$-estradiol using sunlight and UV irradiation (Zhang and Zhou 20 o8). The study confirmed t he use of $\mathrm{U} V$ photodegradation to be far more efficient than solar irradiation, and this was ascribed to the vigorous absorbance of ultraviolet energy by EDCs, although the method did not depend on initial chemical concentration or sample matrix. Thus, heterogeneous photocatalysis was confirmed as a very effective method for removal of

\section{http://repository.uwc.ac.za}


EDCs from water. Sin et al. (2012) in his review article submitted that heterogeneous photocatalysis in the presence of UV, solar light, and oxygen is highly effective for the removal and decomposition of EDCs in water. The authors established that the degradation efficiency is influenced by solution $\mathrm{pH}$, reaction temperature, light intensity and wavelength, catalyst loading, and initial substrate concentration. The study on the adsorption and photocatalytic degradation of 15 different pharmaceuticals by titanium dioxide $\left(\mathrm{TiO}_{2}\right)$ anatase and rutile nanowires together with commercially available $\mathrm{TiO}_{2}(\mathrm{P} 25)$ nanoparticles in the presence or absence of UV were investigated by Hu et al. (2012). The UV-exposed anatase nanowires effectively mineralized venlafaxin, atorvastatin, ibuprofen, naproxen, and gemfibrozil while the effective removal of fluoxetine and norfluoxetine was by rutile-phase nanowires. The exposure to $265 \mathrm{~nm}$ UV effectively decayed sulfamethoxazole and atrazine. The kinetic studies showed that the removals of the pollutants were completed within 20-40 min. Rengaraj and $\mathrm{Li}$ (2011) established the photocatalytic degradation of bisphenol A under UV illumination. Ultrasonic-assisted sol-gel method was used to synthesize and characterize Ag-doped titania. The characterization was done using SEM, EDX, XRD, XPS, and UV-visible absorption spectroscopy. The loading of $\mathrm{Ag}$ on $\mathrm{TiO}_{2}$ catalysts significantly hastened the photocatalytic oxidation of BPA in aqueous suspension. The reaction mechanism specified that the nanosized $\mathrm{Ag}$ doped on $\mathrm{TiO}_{2}$ nanocomposites acted as the center for electron capture where the reduction of oxygen took place. This reduction of oxygen by means of the separation in $\mathrm{Ag}-\mathrm{TiO}_{2}$ nanocomposites was responsible for the faster BPA degradation rate compared with pure $\mathrm{TiO}_{2}$ particles. Also, Fabiola et al. (2008) revealed that the degradation of naproxen in a $0.078 \mathrm{~L}$ Duran reactor equipped with a 1 kW Xe-lamp using $\mathrm{TiO}_{2}$ as photocatalyst did not only confirm photocatalysis treatment as a highly efficient technique but recommend further improvement in the biodegradability under the operational conditions tested.

However, Zhang et al. (2010) appraised the photocatalytic oxidation of endocrinedisruptors, Escherichia coliform (Escherichia coli) as well as the estrogenic activity of a secondary effluents obtainable from a wastewater treatment plant using a photocatalytic reactor coated with $\mathrm{TiO}_{2}$. Filtration followed by photocatalysis was used to compare the reduction rate of estrogenic activity and E. coli in both filtered and unfiltered wastewater samples. The inactivation rate of E. coli and estrogenic activity improved considerably after filtration which was ascribed to the partial removal of suspended solids which thus enhanced the photocatalytic oxidation. Combined photocatalysis with filtration pretreatment was reported to be effective. Lin et al. (2013) utilized immobilized $\mathrm{TiO}_{2}$ photocatalyst supported on a fiberglass to photo mineralize ibuprofen.

\section{http://repository.uwc.ac.za}




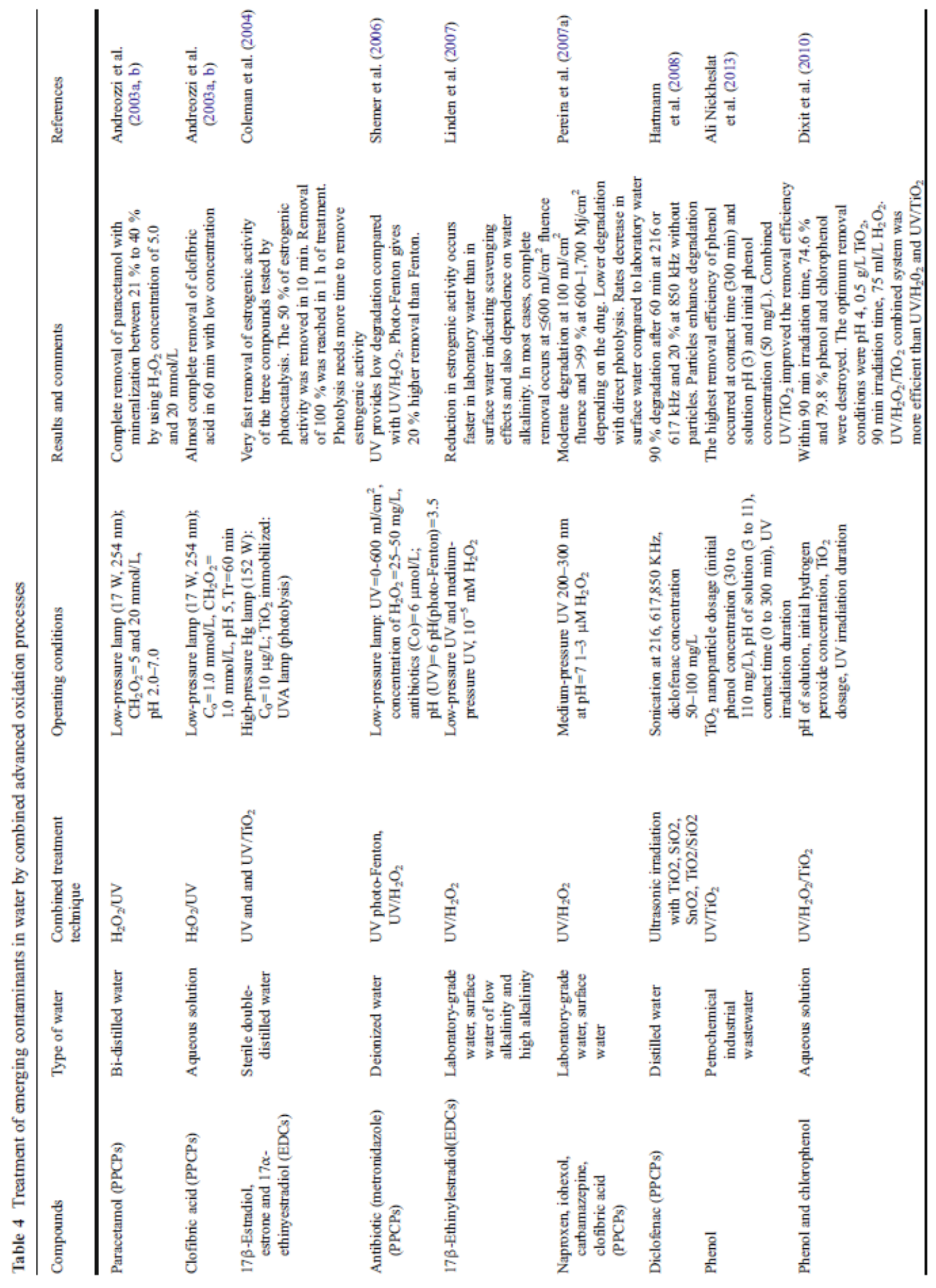

http://repository.uwc.ac.za 


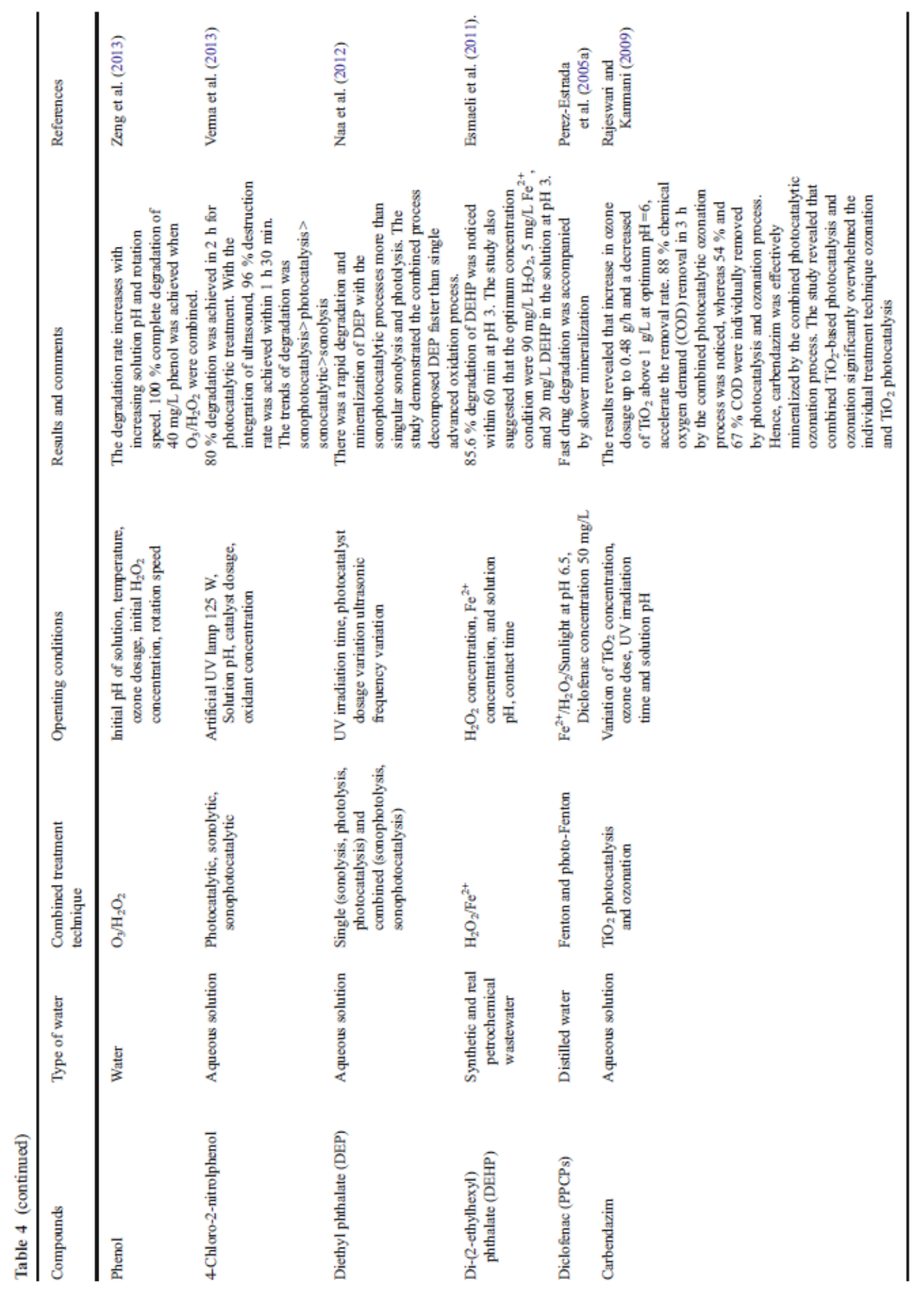

http://repository.uwc.ac.za 


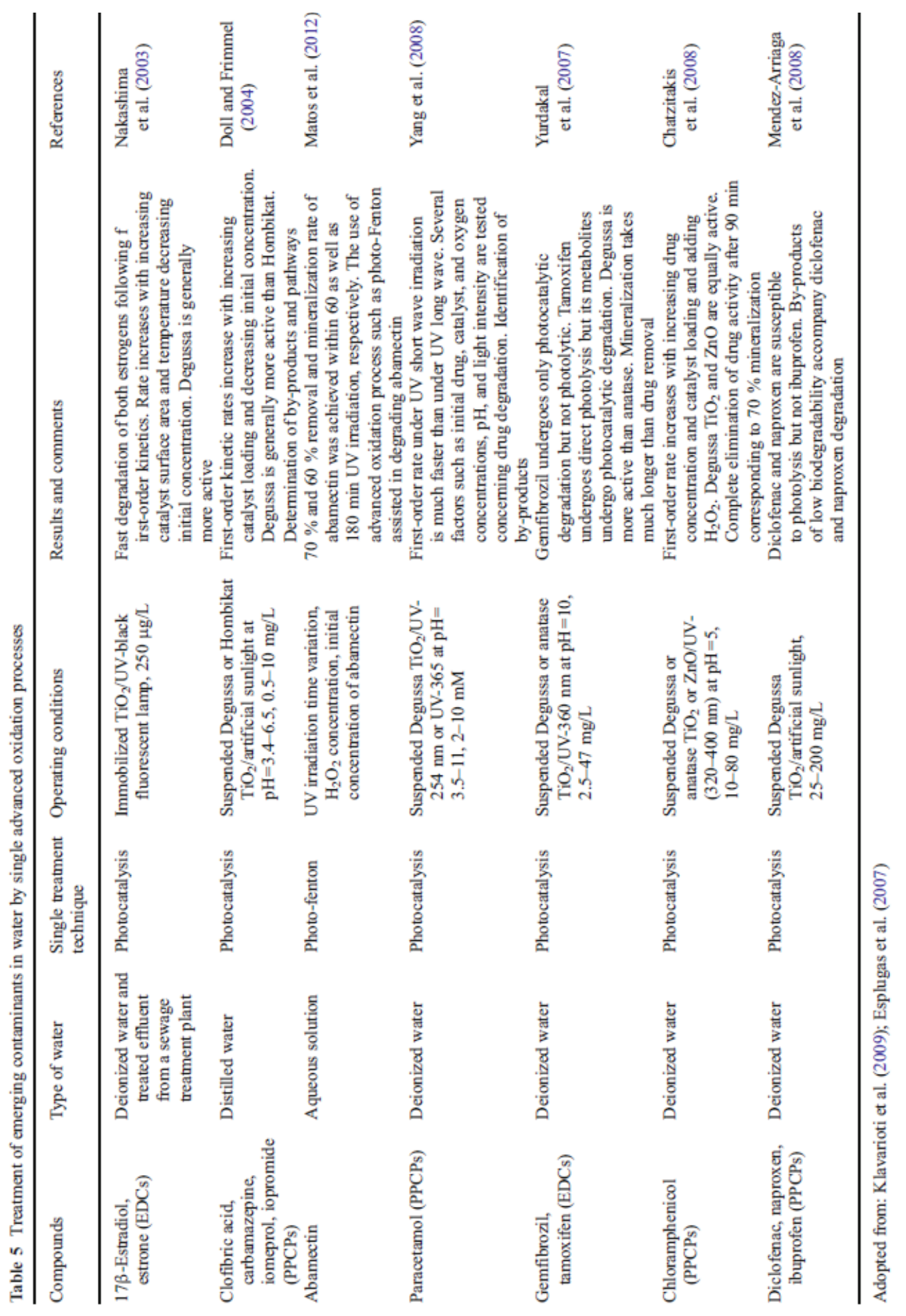

The authors established direct relationship between photocatalytic dosage and contaminant degradation rate. Addition of $\mathrm{H}_{2} \mathrm{O}_{2}$ significantly enhanced the decomposition rate. In the same vein, Madhavan et al. (2010) investigated the combined effect of sonolysis, photocatalysis, and sonophotocatalysis on the degradation of ibuprofen. The authors discovered that the obtained degradation rate from sonophotocatalysis was significantly higher than the individual advanced oxidation processes studied. The synergy index value of combined advanced oxidation was 0.3 greater than individual sonolytic and

\section{http://repository.uwc.ac.za}


photocatalytic process. Equally, Frontistis et al. (2012) reported the efficiency of the combined photocatalysis and ultrasonic irradiation regarding 17a-ethynylestradiol (EE2) degradation in aqueous solution. The study established a synergistic effect rather than a cumulative action between the two combined systems. In fact, increase in catalyst dosage and photon flux together with a decrease matrix complexity was responsible for estrogen concentration changes. So far, this review has shown that photocatalysis using titania or its immobilized form may be useful in degrading and completely mineralizing some of the PPCPs and EDCs in contaminated water.

\subsubsection{Homogeneous Advanced Oxidation Processes}

Homogeneous advanced oxidation process is a reaction process in which both the reactant and photocatalysis are in the same phase. Most of the commonly used homogeneous photocatalysis are ozone, metal oxide, metal oxide/hydrogen peroxide, etc. The mineralization and decomposition of emerging micropollutants by homogeneous advanced treatment therefore exploits ozone, hydrogen peroxide, ultraviolet light, or combined process using a combination of ozone and hydrogen peroxide, hydrogen peroxide, and ultraviolet light, ozone/ultraviolet light/ferrous ions or ferric ions, ferrous or ferric ions/hydrogen peroxide, ferrous or ferric ions/ultraviolet light to degrade toxic pollutants. This section review some of the previous research conducted using either single or combined system to destroy the contaminants of emerging concern. Xu et al. (2007) demonstrated ozone oxidation technique to investigate the degradation of endocrine disruptor bisphenol A in drinking water. The effects of different ozone dosages, BPA initial concentrations, and ozone adding time were monitored in a reactor. The outcome of the study revealed that ozone dosage plays a dominant role during the process of BPA degradation, while the impact of the contact time could be ignored, although high ozone dosage, and dissolved ozone concentration greatly contributed to the extent of BPA degradation. Thus, the $\mathrm{O}_{3}-\mathrm{H}_{2} \mathrm{O}_{2}$ processes proved to have similar effects on the degradation of BPA by ozone oxidation. Li et al. (2011) reported the pentachlorophenol (PCP) removal under xenon lamp irradiation in presence of metal oxide bismuth silicate (BSO). A mineralization rate of $99.1 \%$ after 120 min was observed. Decrease in $\mathrm{pH}$ was observed from $\mathrm{pH} 6.2$ to 4.6. The electron spin resonance results indicated that the degradation mechanism was largely due to the presence of superoxide radical $\left(\mathrm{O}_{2}{ }^{-}\right)$, and the GC-MS analysis confirmed the presence of some intermediates, mainly aromatic compounds and aliphatic carboxylic acids. Table 2 captures other single treatment techniques used to remove and degrade emerging micropollutants.

Furthermore, a review conducted by Ning et al. (2007) showed that the combination of ozone and other ozone-based advanced oxidation process were highly efficient in destroying steroidal estrogenic hormones such as estrone (E1), 17b-estradiol (E2), estriol (E3), and 17aethinylestradiol (EE2), except phthalates suspected resist degradation by ozone. Pereira et al. (2007) explored two homogeneous advanced oxidation processes such as $\mathrm{UV}$ and $\mathrm{UV} / \mathrm{H}_{2} \mathrm{O}_{2}$ to degrade pharmaceutically active substances fond in aqeous water. The authors discovered that integration of hydrogen peroxide significantly enhanced the

\section{http://repository.uwc.ac.za}


overall degradation efficiency of the pollutants. Hence, combined $\mathrm{UV} / \mathrm{H}_{2} \mathrm{O}_{2}$ was revealed to be a viable option for degradation of the pollutants. Giri et al. (2010) utilized seven different advanced oxidation methods such as $\mathrm{UV}, \mathrm{UV} / \mathrm{TiO}_{2}, \mathrm{UV} / \mathrm{H}_{2} \mathrm{O}_{2}, \mathrm{O}_{3}, \mathrm{O}_{3} / \mathrm{UV}$, $\mathrm{O}_{3} / \mathrm{TiO}_{2}$, and $\mathrm{O}_{3} / \mathrm{UV} / \mathrm{TiO}_{2}$ to remove and degrade selected PPCPs in aqueous solution. The authors observed four different removal patterns which include nondegradation by any of the seven techniques, degradation by ozone-based, and not ultraviolet, system, degradation by ultraviolet, and not ozone-based, techniques. In addition, the degradation of the pollutants by combined ozonation and ultraviolet was rapid and efficient. Zelmanov and Semiat (2008) demonstrated that iron(III) oxide nanocatalyst combined with hydrogen peroxide could effectively degraded water contaminated with phenol and ethylene glycol without necessarily exposing the solution to ultraviolet or photolight. The authors concluded that the degradation rate of phenol and ethylene glycol was 35 times and two to four times greater than the literature value reported for Fenton process and UV. Kim et al. (2009) reported that $\mathrm{H}_{2} \mathrm{O}_{2}$ addition aided the photodegradation of PPCPs during UV treatment and found that the average first-order rate constant value for all the PPCPs studied increased by a factor of 1.3 when $\mathrm{H}_{2} \mathrm{O}_{2}$ was added during UV treatment. The addition of $\mathrm{H}_{2} \mathrm{O}_{2}$ improved the photodegradation rates of PPCPs appreciably during UV treatment. Equally, Nakonechnya et al. (2008) explored ozone and hydrogen peroxide combination to degrade steroidal hormone estrone (E1). The authors observed that the E1 degradation was found to depend on $\mathrm{pH}$ and $\mathrm{O}_{3} / \mathrm{H}_{2} \mathrm{O}_{2}$ ratio. Thus, the combination of $\mathrm{O}_{3} / \mathrm{H}_{2} \mathrm{O}_{2}$ proved to be highly efficient treatment for E1. Lopez et al. (2003) argued that $\mathrm{UV}$ and $\mathrm{UV} / \mathrm{H}_{2} \mathrm{O}_{2}$ treatment methods were able to oxidize pharmaceutical intermediates such as 5-methyl-1,3,4-thiadiazole-2-methyl thiol ( MMTD-Me) while the d irect photodegradation of the two pharmaceutical intermediates have shown that the intermediate with lower concentration degraded faster. Vogna et al. (2004a) proposed diclofenac oxidation using combined $\mathrm{UV} / \mathrm{H}_{2} \mathrm{O}_{2}$ and ozonation technique and were found to be feasible and viable in bringing about complete mineralization of diclofenac. In another study, the $\mathrm{UV} / \mathrm{H}_{2} \mathrm{O}_{2}$ method was effective in removing carbamazepine while UV alone was not efficient to reduce the carbamazepine concentration (Vogna et al. 2004b.)

However, other AOPs such as ultrasonic irradiation with widespread application of degrading organic pollutants present in wastewater have equally been examined (Shannon et al. 2008). These methods oxidize the complex organic matter found to be extremely difficult to degrade biologically into simpler end products. The reported complete degradation and mineralization potential was ascribed to the reactive nature of the generated free active species most predominantly hydroxyl radical (Giri et al. 2010). The radical was reported to be non-selective and highly reactive with higher oxidation potential of $2.33 \mathrm{~V}$ when compared with other conventional oxidizing agents such as $\mathrm{H}_{2} \mathrm{O}_{2}$ or $\mathrm{KMnO}_{4}$ (Gogate and Pandit 2004). Xiao et al. (2013) combined continuous wave (CW) and pulsed wave (PW) ultrasound to degrade carbamazepine, ibuprofen, acetaminophen, sulfamethoxazole, ciprofloxacin, propyl gallate, and diethyl phthalate. The findings showed that degradation rates of the pollutants were quicker for smaller compounds but less rapid for larger compounds by PW ultrasound than that achieved under CW ultrasound. The

\section{http://repository.uwc.ac.za}


introduction of hydroxyl radical trapping agent, acetic acid, to PPCPs solutions aided in degrading certain fractions within the bulk solution that were positively interrelated with the molar volume of the compound. Chong et al. (2012) joined an integrated membrane bioreactor with titanium dioxide photocatalyst $\left(\mathrm{MBR}-\mathrm{TiO}_{2}\right)$ to mineralize $\mathrm{CBZ}$ from pharmaceutical wastewater. The individual systems of $\mathrm{MBR}$ and $\mathrm{TiO}_{2}$ photocatalytic technology were monitored separately so as to establish the synergistic operational effects. The respirometric test showed that CBZ introduction acts as a chemical stressor that influenced the biomass metabolism in the MBR which resulted in the reduction of sludge yield. The combined MBR$\mathrm{TiO}_{2}$ system operated at 4:1 ratio condensed the chemical stressor effects and a maximum of $95 \%$ CBZ removal efficiency was observed. However, despite the success story of efficient degradation of emergent contaminants by credited to various advanced oxidation processes, high operational cost still limits it widely acceptance especially in the emergent nations. Therefore, the integration of less expensive treatment process such as adsorption with advanced oxidation process will further enhance and accelerate the degradation rate of organic pollutants.

\subsubsection{Combined Advanced Oxidation Processes with Biological and Physical Treatment}

As stated earlier, wastewater treatment containing organic pollutants is complex, expensive, and time-consuming. The survey of literatures revealed that most wastewater treatment plants are not designed for emergent pollutants removal. Therefore, a more practical, versatile, and economical technique is needed. Ever since the identification and detection emergent micropollutants in terrestrial and aquatic environment, numerous treatment processes such as biological and physicochemical methods have been exploited and explored. However, AOPs and other conventional treatment option such as physicochemical treatment have been applied to remove pharmaceuticals and endocrine disruptors from wastewater. Advanced oxidation process coupled with biological process is not often effective against the target pollutants degradation due to the inhibitory effect of hydroxyl radicals by the biomass. The physical treatment such as filtration can be employed before or after the advanced oxidation process. Thus, the application of physical and biological methods helps to remove large insoluble particles, reducing turbidity and interfering ions from the aqueous matrix. Once all these are removed, the degradation efficiency of AOPs will be improved. An overview on the combined AOPs with physical or biological treatment is as follows. Ozonation as one of the AOPs is employed as a preoxidation step in a combined treatment line. The combination of ozonation and a moving-bed biofilm reactor to remove estrogenic substances from a conventional activated-sludge treatment was reported by Gunnarsson et al. (2009). Ozonation was used as a pre-treatment step to enhance anaerobic digestion stability of the modelled compounds (Carballa et al. 2007). Not only that, chemical oxygen demand solubilization of $60 \%$ was achieved, thus hastening the destruction of the soluble organic matter during anaerobic digestion. Also, photo-Fenton process was integrated with a biological system to degrade $a-$ methylphenylglycine by Oller et al. (2007a). It was observed that the combined system enhanced the biodegradability and broad elimination of bio-refractory compound (Oller et al. 2007). The coupled technology was able to remove $95 \%$ of total organic carbon (Oller et

\section{http://repository.uwc.ac.za}


al. 2011). José et al. (2010) reported that the removal of carbamazepine, clofibric acid, diclofenac, and diazepam from municipal wastewater using biological treatment failed to completely eliminate the pollutants, but incorporation of membrane bioreactor and advanced oxidation processes such as $\mathrm{O}_{3}, \mathrm{O}_{3} / \mathrm{UV}, \mathrm{O}_{3} / \mathrm{H}_{2} \mathrm{O}_{2}$, and $\mathrm{UV} / \mathrm{H}_{2} \mathrm{O}_{2}$ effectively achieved complete removal. Nakada et al. (2007) studied the removal of some pharmaceuticals and endocrine disruptors present in municipal wastewater by combined sand filtration and ozonation. It was stressed that the combined efforts of ozone and sand filtration with sludge treatment enhanced the elimination of $80 \%$ of the model pollutants. Ozonation was noted to play the dominant role. In another study, combined advanced oxidation and a biological treatment process was used to remove pesticides from an aqueous matrix. It was observed that the biological treatment assisted in removing the bulk of the chemical oxygen demand while $\mathrm{O}_{3} / \mathrm{UV}$ enhanced the pesticide decomposition (Lafi and Al-Qodah 2006). Rossnera et al. (2009) utilized three different adsorbents such as activated carbon, carbonaceous resin, and high-silica zeolite to remove EDCs, PPCPs, and flame retardant. Activated carbon was only able to achieve a two-log elimination of the modelled compounds. The incorporation of advanced oxidation processes enhanced the degradation rate. Badawy et al. (2009) utilized combined Fenton and biological treatment process to eliminate some pharmaceuticals from industrial wastewater. The authors revealed that recalcitrant toxic pollutants were partially removed by biological treatment and successfully destroyed by the Fenton process. Thus, the integrated system is more advantageous and capable of completely eliminate hazardous persistent pollutants in water and wastewater.

Liu et al. (2009) reviewed the removal mechanism of endocrine disruptors in wastewater treatment using three different methods such as physical, biodegradation, and chemical advanced oxidation processes. The authors recognized that physical and advanced oxidation processes such as ozone/hydrogen peroxide are more advantageous with respect to removal and degradation efficiency while a biodegradation process among which activated sludge treatment was observed to reduce the level of EDCs in surface water. Hence, physical, biological, and chemical advanced oxidation could be combined to improve the removal performance of EDCs.

\section{Detection and Quantification of Emerging Micropollutants}

The contaminants of emerging concern are structurally complex, and the probability of being highly present in drinking water is increasing due to ever-increasing population density driven by high demand of new chemicals in the market (Marchesini et al. 2007). There is a need to urgently adopt fast and sensitive analytical protocols that can screen, detect, and quantify a large diversity of composites concurrently. This becomes necessary as the various known analytical equipment including liquid chromatography combined with mass spectrometry (LC-MS), high-performance-liquid chromatography (HPLC), liquid chromatography coupled with electrochemical detection (LC-ED), capillary electrophoresis (CE), and gas chromatography coupled with mass spectrometry (GC-MS) used so far are not without some challenges (Gatidou et al. 2007; Comerton et al. 2009; Mottaleb et al. 2009). Presently, most of these instruments are too cumbersome in analyzing

\section{http://repository.uwc.ac.za}


samples, and despite the long sample pre-treatment, the equipment can only detect or identify a small range of similar contaminant at a time in the matrices. Apart from this, long preconcentration steps, lack of rapid processing and detection of sample, and time-consuming analysis negates the continuous use of these analytical instruments. Also, lack of portability and suitability during field work constitute another challenge (Huertas-Perez and Garcia-Campana 2008; Blazkova et al. 2009; Le Blanc et al. 2009). Not only these, the sophisticated and costly nature of the equipment, their labor-energy-intensive nature coupled with the need of the derivatization of samples in the case of (GC-MS) prior to analysis form the basis to develop more simple and robust instrumental techniques that are affordable, durable, and easy to maintain. Sensors and biosensors are presently seen as a replacement to those aforementioned instruments. Iwuoha (2012) established that sensor materials were more sensitive in determining and quantifying the emerging micropollutants than other reported analytical equipment such as GC-MS. Sensors and biosensors, for instance, are presently considered as an alternative to those aforementioned expensive instruments due to the ease of operation and elimination of the pretreatment steps, lower consumption time, higher sensitivity, and fast responses (Yin et al. 2009). Other benefits include easy determination of pollutants in multifaceted media without rigorous sample preparation (Rodriguez-Mozaz et al. 2006). Presently, large numbers of biosensors developed are still in the laboratory stage and need to be certified before bulk manufacture and use (Rodriguez-Mozaz et al. 2006; Farré et al. 2009). Apart from providing information on the chemical composition of the sample, biological activity such as toxicity and endocrine-disrupting effect can also be obtained. The development of more sensors and biosensors should be the top priority in the nearest future. This should be standardized for easy detection and quantification of emerging micropollutants. Without functional and practicable analytical tools, determination, and quantification of the environmental fate, and behavior of these emergent pollutants will be a mirage. However, despite the simplicity in the use of biosensors to detect EDCs and PPCPs, one major challenge is that biosensors is specific and can only sense a micropollutant at a time. This mean a lot of biosensors need to be developed which will require additional cost and time. Therefore, simple analytical technique such as total organic carbon (TOC) is recommended as a high level of TOC in water or wastewater signifies huge pollutants load. Hence, the water or wastewater necessitates treatment.

\section{Conclusion and Recommended Interventions}

Advanced oxidation processes can degrade these contaminants without necessarily adding complex chemicals. This is a much green and less complex route than many other options, if energy consumption can be reduced. Although free radicals are short-lived and do the job rapidly without leaving long-term residues when applied properly but need to be managed so as not to leave partially degraded secondary pollutants. The continuous reported adverse health challenges occasioned by poor or partial elimination and degradation of emerging micropollutants by single treatment techniques in drinking water also require urgent interventions. This means that the current single treatment system has failed to do the job and instead of detoxifying the contaminants acts as a point source of environmental contamination. The removal of PPCPs/EDCs from contaminated water is a challenging task due to the complexity and persistence of the pollutants in water. Thus,

\section{http://repository.uwc.ac.za}


there is a need to urgently adopt the use of combined advanced oxidation techniques to treat wastewater contaminated by emerging pollutants. Combined advanced oxidation techniques offer the potential to drastically reduce the health and environmental effects of persistent organic pollutants and endocrine disruptors. Hence, the new approaches will help to maintain public health together with environmental sustainability. The combined technology offers the hope that adequate water purification will not only contribute to the production of safer water for drinking purpose but also eliminate the resurfacing of by-products after single-stage wastewater treatments. This will go a long way to putting to rest the issue of heightened fears concerning the safety of drinking water. Not only this, the task of water regulatory agencies will also become less onerous with regards the treatment of the contaminated water. Emerging micropollutants are now recognized as a problematic issue due to their bioaccumulation in the environment owing to their accidental discharge. A lot still needs to be done, among which is the establishment of monitoring teams to enforce the environmental regulations. There is also a great need to continuously carry out a thorough routine toxicological analysis of drinking water so as to establish the exposure limits to PPCPs/EDCs in humans. Water regulatory agencies need to be informed of the proper treatment technique to adopt while treating tainted wastewater. Future research should also include re-designing and upgrading conventional wastewater treatment plants in urban centers to accommodate the latest technology of degrading and mineralizing emerging pollutants. This will contribute in no small measure to the quality of drinking water. The research on emerging contaminants should be extended to the developing countries where the extent of the deterioration of water sources needs to be established, which will aid the water industry and the policy makers to choose the appropriate advanced water treatment techniques to use for degrading PPCPs/EDCs in water. Biosensors need to be further developed for rapid detection of specific contaminants. In order to have a natural ecosystem that is completely free of pharmaceuticals and endocrine-disrupting compounds, there is a need to introduce green chemistry in the production and development of numerous drugs, medical, and personal care products that are affordable and do not persist in the environment. A regulatory framework based on the precautionary principle should be implemented to screen all compounds for their ecotoxicity prior to approval for use.

\section{Acknowledgments}

The authors acknowledge Environmental and Nano Sciences Research Group, Department of Chemistry, University of the Western Cape, South Africa, for the assistance.

\section{http://repository.uwc.ac.za}




\section{References}

Ali Nickheslat., Mohammad Mehdi Amin, Hassan Izanloo, Ali Fatehizadeh, \& Seyed Mohammad Mousavi. (2013). Phenol Photocatalytic Degradation by Advanced Oxidation Process under Ultraviolet Radiation Using Titanium Dioxide. Journal of Environmental and Public Health, Volume 2013 (2013), Article ID 815310, 9 pages

Al-Rifai, J. H., Khabbaz, H., \& Schäfer, A. I. (2011). Removal of pharmaceuticals and endocrine disrupting compounds in a water recycling process using reverse osmosis systems. Separation and Purification Technology, 77, 60-67.

Andersson, A. M., Jensen, T. K., Juul, A., Petersen, J. H., Jorgensen, T., \& Skakkebaek, N. E. (2007). Secular decline in male testosterone and sex hormone binding globulin serum levels in Danish population surveys. Journal of Clinical Endocrinology and Metabolism, 92, 4696-4705.

Andreozzi, R., Caprio, V., Marotta, R., \& Vogna, D. (2003a). Paracetamol oxidation from aqueous solutions by means of ozonation and $\mathrm{H}_{2} \mathrm{O}_{2}$ /UV system. Water Research, 37, 993-1004.

Andreozzi, R., Caprio, V., Marotta, R., \& Radovnikovic, A. (2003b). Ozonation and $\mathrm{H}_{2} \mathrm{O}_{2} / \mathrm{UV}$ treatment of clofibric acid in water: A kinetic investigation. Journal of Hazardous Materials, 103, 233-246.

Ankley, G. T., Brooks, B. W., Huggett, D. B., \& Sumpter, J. P. (2007). Repeating history: Pharmaceuticals in the environment. Environmental Science and Technology, 41, 82118217.

Ashiya, B., \& Guatam, S. K. (2011). Application of Photocatalysis for the degradation of Endocrine disrupting chemicals: Endosulphan and lindane. IJEP, 31(8), 658-665.

Ashton, D., Hilton, M., \& Thomas, K. V. (2004). Investigating the environmental transport of human pharmaceuticals to streams in the United Kingdom. Science of the Total Environment, 333, 167-184. doi:10.1016/j.scitotenv.2004.04.062.

Assmuth, T., \& Louekari, K. (2001). Research for management of environmental risks from endocrine disrupters - contexts, knowledge base, methodologies and strategies. Helsinki: Finnish Environment Institute.

Badawy, M. I., Wahaab, R. A., \& El-Kalliny, A. S. (2009). Fenton-biological treatment processes for the removal of some pharmaceuticals from industrial wastewater. Journal of Hazardous Materials, 167, 567-574.

Barnes, K.K., Kolpin, D.W., Meyer, M.T., Thurman, E.M., Furlong, E.T and Zaugg, S.D (2002). Water quality data for pharmaceuticals, hormones, and other organic wastewater contaminants in U.S. streams, 1999-2000. United States Geological Survey.

Barnhoorn, I. E. J., Bornman, M. S., Pieterssse, G. M., \& Vuren, J. H. J. (2004). Histological evidence of intersex in feral sharptooth catfish (Clarias gariepinus) from an estrogenpolluted water source in Gauteng, South Africa. Environmental Toxicology, 19, 603608.

Belgiorno, V., Rizzo, L., Fatta, D., Rocca, C. D., Lofrano, G., Nikolaou, A., Naddeo, V., \& Meric, S. (2007). Review on endocrine disrupting-emerging compounds in urban wastewater: Occurrence and removal by photocatalysis and ultrasonic irradiation for wastewater reuse. Desalination, 215,166-176. 
Benotti, M. J., Trenholm, R. A., Vanderford, B. J., Standford, B. D., \& Snyder, S. A. (2009). Pharmaceuticals and endocrine disrupting c ompoun ds in U.S. drinking water. Environmental Science and Technology, 43, 597-603.

Besse, J. P., \& Garric, J. (2009). Progestagens for human use, exposure and hazard assessment for the aquatic environment. Environ Pollution, 157, 3485-3494.

Besse, J. P., Kausch Barreto, C., \& Garric, J. (2008). Exposure assessment of pharmaceuticals and their metabolites in the aquatic environment: Application to the French situation and preliminary prioritization. J Human Ecol Ris Assess, 14(4), 665695.

Besse, J. P., Latour, J. F., \& Garric, J. (2012). Anticancer drugs in surface waters. What can we say about the occurrence and environmental significance of cytotoxic, cytostatic and endocrine therapy drugs? Environmental International, 39, 73-86.

Bisceglia, K.J. \& Roberts, A.L. (2006). A usage study and preliminary environmental risk assessment for human pharmaceuticals in the United States. Environ. Sci. Technol., in preparation.

Blazkova, M., Mickova-Holubova, B., Rauch, P., \& Fukal, L. (2009). Immunochromatographic colloidal carbon-based assay for detection of methiocarb in surface water. Biosensors and Bioelectronics, 25(4), 753-758.

Bolong, N., Ismail, A. F., Salim, M. R., \& Matsuura, T. (2009). A review of the effects of emerging contaminants in wastewater and options for their removal. Desalination, 239,229-246.

Bonefeld-Jorgensen, E. C., Long, M., Hofmeister, M. V., \& Vinggaard, A. M. (2007). Endocrine-disrupting potential of bisphenol A, bisphenol A dimethacrylate, 4-nnonylphenol, and 4-n-octylphenol in vitro: New data and a brief review. Environmental Health Perspectives, 115(Suppl. 1), 69-76.

Bound, J. P., \& Voulvoulis, N. (2005). Household disposal of pharmaceuticals as a pathway for aquatic contamination in the United Kingdom. Environ. Health Perspectives, 113, $1705-1711$.

Boxall, A. B. A., Fogg, L. A., Blackwell, P. A., Kay, P., Pemberton, E. J., \& Croxford, A. (2004). Veterinary medicines in the environment. Reviews of Environmental Contamination and Toxicology, 180, 1-91.

Boyd, G. R., Reemtsma, H., Grimm, D. A., \& Mitra, S. (2003). Pharmaceuticals and personal care products (PPCPs) in surface and treated waters of Louisiana, USA and Ontario, Canada. Science of the Total Environment, 311, 135-149.

Braga, O., Smythe, G. A., Schafer, A. I., \& Feitz, A. J. (2005). Fate of steroid estrogens in Australian inland and coastal wastewater treatment plants. Environmental Science Technology 39, 3351-3358.

Brausch, J. M., \& Rand, G. M. (2011). A review of personal care products in the aquatic environment: Environmental concentrations and toxicity. Chemosphere, 82, 15181532. Brooks, B. W., Riley, T. M., \& Taylor, R. D. (2006). Water quality of effluentdominated stream ecosystems: Ecotoxicological, hydrological, and management considerations. Hydrobiologia, 556, 365-379. 
Burkhardt-Holm, P., Giger, W., Güttinger, H., Ochsenbein, U., Peter, A., Scheurer, K., Suter, M. J. F., Ochsenbein, U., Segner, H., \& Staub, E. (2005). Where have all the fish gone. Environmental Science and Technology, 39, 441A-447A.

Caliman, F. A., \& Gavrilescu, M. (2009). Pharmaceuticals, personal care products and endocrine disrupting agents in the environment - a review. Clean, 37(4-5), 277-303.

Campbell, C. G., Borglin, S. E., Green, F. B., Grason, A., Wozei, E., \& Stringfellow, W. T. (2006). Biologically directed environmental monitoring, fate, and transport of estrogenic endocrine disrupting compounds in water: A review. Chemosphere, 65, $1265-1280$.

Carballa, M., Omil, F., Lema, J. M., Llompart, M., Garcia-Jares, C., Rodriguez, I., Gomez, M., \& Ternes, T. (2004). Behavior of pharmaceuticals, cosmetics and hormones in a sewage treatment plant. Water Research, 38, 2918-2926.

Carballa, M., Manterola, G., Larrea, L., Ternes, T., Omil, F., \& Lema, J. M. (2007). Influence of ozone pretreatment on sludge anaerobic digestion: Removal of pharmaceutical and personal care products. Chemosphere, 67, 1444-1452.

Chatzitakis, A., Berberidou, C., Paspaltsis, I., Kyriakou, G., Sklaviadis, T., \& Poulios, I. (2008). Photocatalytic degradation and drug activity reduction of chloramphenicol. Water Research, 42, 386-394.

Chong, M. N., \& Jin, B. (2012). Photocatalytic treatment of high concentration carbamazepine in synthetic hospital wastewater. Journal of Hazardous Materials, 199-200, 135-142.

Chong, M. N., Jin, B., Laera, G., \& Christopher, P. S. (2011). Evaluating the photodegradation of Carbamazepine in a sequential batch photoreactor system: Impacts of effluent organic matter and inorganic ions. Chemical Engineering Journal, 174, 595-602.

Chong, M.N., Laera, G. \& Jin, B. (2012). Integrating membrane bioreactor with advanced $\mathrm{TiO}_{2}$ photocatalytic technology for the removal of pharmaceutical drugs from recycled wastewater. $9^{\text {th }}$ IWA Leading-Edge Conference on Water and Wastewater Technologies.

Coleman, H. M., Routledge, E. J., Sumpter, J. P., Eggins, B. R., \& Byrne, J. A. (2004). Rapid loss of estrogenicity of steroid estrogens by UVA photolysis and photocatalysis over an immobilized titanium dioxide catalyst. Water Research, 38, 3233-3240.

Comerton, A. M., Andrews, R. C. \& Bagley, D. M. (2009). Practical overview of analytical methods for endocrine disrupting compounds, pharmaceuticals and personal care products in water and wastewater. Philosophical Transactions of Royal Society A, 367(1904), 3923-3939.

Cortés Muñoz, J.E., Calderón Mólgora, G.C., Martín Domínguez, A., Espino de la O, E.E. Gelover Santiago, S.L., Hernández Martínez, C.L., Moeller Chávez, G.E. (2013). Endocrine disruptors in water sources: Human health risks a, INTECH Publisher (pp 1)

Czech Bozena and Rubinowska Katarzyna. (2013). $\mathrm{TiO}_{2}$-assisted photocatalytic degradation of diclofenac, metoprolol, estrone and chloramphenicol as endocrine disruptors in water. Adsorption, 19, 619-630.

Daughton, C. G. (2002). Environmental stewardship and drugs as pollutants. Lancet, 360, $1035-1036$. 
Daughton, C. G. (2004). Non-regulated water contaminants: Emerging research. Environmental Impact Assessment Review, 24(7-8), 711-732.

Daughton, C. G., \& Ternes, T. A. (1999). Pharmaceuticals and personal care products in the environment: Agents of subtle change? Environmental Health Perspectives, 107, 907938.

Davies, L., \& Welch, H. G. (2006). Increasing incidence of thyroid cancer in the United States, 1973-2002. JAMA, 295, 2164-2167.

Dean, C. (2007). Drugs Are in the Water. Does It Matter?http:// www.nytimes.com/2007/04/03/science/earth/o3water. html?_r1/42\&s q 1/4 cor nelia\% 2 od rinking \% 2owater\&st $1 / 4$ nyt\&scp $1 / 42$ \&pagewanted $1 / 4$ all. Accessed 5 Nov 2009.

Diamanti-Kandarakis, E., Bourguignon, J. P., \& Giudice, L. C. (2009). Endocrine disrupting chemicals: An Endocrine Society scientific statement. Endocrine Reviews, 30, 293- 342.

Dixit, A., Mungray, A. K., \& Chakraborty, M. (2010). Photochemical oxidation of phenol and chlorophenol by $\mathrm{UV} / \mathrm{H}_{2} \mathrm{O}_{2} / \mathrm{TiO}_{2}$ process: A kinetic study. International Journal of Chemical Engineering and Applications, 1(3), 247-250.

Doll, T. E., \& Frimmel, F. H. (2004). Kinetic study of photocatalytic degradation of carbamazepine, clofibric acid, iomeprol and iopromide assisted by different $\mathrm{TiO}_{2}$ materials determination of intermediates and reaction pathways. Water Research, 38 , 955-964.

Ellis, J. B. (2006). Pharmaceutical and personal care products (PPCPs) in urban receiving waters. Environm. Poll, 144, 184-189.

Enewold, L., Zhu, K., \& Ron, E. (2009). Rising thyroid cancer incidence in the United States by demographic and tumor characteristics, 1980-2005. Cancer Epidemiology, Biomarkers and Prevention, 18, 784-791.

Esmaeli, R., Hassani, A. H., Eslami, A., Ahmadi Moghadam, M., \& Safari, A. A. (2011). Di(2-ethylhexyl) phthalate oxidative degradation by Fenton process in synthetic and real petrochemical wastewater. Iran. J. Environ. Health. Sci. Eng., 8(3), 201-206.

Esplugas, S., Bila, D. M., Krause, L. G. T., \& Dezotti, M. (2007). Ozonation and advanced oxidation technologies to remove endocrine disrupting chemicals (EDCs) and pharmaceuticals and personal care products (PPCPs) in water effluents. Journal of Hazardous Materials, 149(3), 631-642.

Fabiola, M.-A., Gimenez, J., \& Esplugas, S. (2008). Photolysis and $\mathrm{TiO}_{2}$ photocatalytic treatment of naproxen: Degradation, mineralization, intermediates and toxicity. J. Adv. Oxid. Technol, 11(3), 436-445.

Falconer, I. R., Chapman, H. F., Moore, M. R., \& Ranmuthugala, G. (2006). Endocrinedisrupting compounds: A review of their challenge to sustainable and safe water supply and water reuse. Environmental Toxicology, 21, 181-191.

Farré, M., Kantiani, L., Perez, S., \& Barcelo, D. (2009). Sensors and biosensors in support of EU Directives. Trends in Analytical Chemistry, 28(2), 170-185.

Fatoki, O. S., \& Opeolu, B. O. (2009). Studies on the occurrence and quantification of phenolic endocrine disruptors in water. Scientific Research and Essay, 4(12), 1415-1422. 
Fawell, J., \& Ong, C. N. (2012). Emerging contaminants and the implications for drinking water. International Journal of Water Resources Development, 28(2), 247-263.

Fent, K., Weston, A. A., \& Caminada, D. (2006). Ecotoxicology of human pharmaceuticals. Aquatic Toxicology, 76, 122-159.

Ferraz, N., Carnevi Nande, G., Rossotti, M., Miguez, M. N., Last, J. A., \& GonzalezSapienza, G. (2007). Specific immunoassays for endocrine disruptomonitoring using recombinant antigens cloned by degenerated primePCR. Analytical and Bioanalytical Chemistry, 389, 2195-2202.

Fick, J., Soderstrom, H., Lindberg, R. H., Phan, C., Tysklind, M., \& Larsson, D. G. J. (2009). Contamination of surface, ground, and drinking water from pharmaceutical production. Environmental Toxicology and Chemistry, 28, 2522-2527.

Flint, S., Markle, T., Thompson, S., \& Wallace, E. (2012). Bisphenol A exposure, effects, and policy: A wildlife perspective. Journal of Environmental Management, 104, 19-34.

Focazio, M. J., Kolpin, D. W., Barnes, K. K., Furlong, E. T., Meyer, M. T., Zaugg, S. D., Barber, L. B., \& Thurman, M. E. (2008). A national reconnaissance for pharmaceuticals and other organic wastewater contaminants in the United States-II) Untreated drinking water sources. Science of the Total Environment, 402, 201-216.

Friedmann, D., Mendive, C., \& Bahnemann, D. (2010). TiO2 for water treatment: parameters affecting the kinetics and mechanisms, of photocatalysis. Applied Catalysis B, 99, 398406.

Frontistis, Z., Daskalaki, V. M., Hapeshi, E., Drosou, C., Fatta-Kassinos, D., Xekoukoulotakis, N. P., \& Mantzavinos, D. (2012). Photocatalytic (UV-A/TiO2) degradation of 17aethynylestradiol in environmental matrices: Experimental studies and artificial neural network modelling. Journal of Photochemistry and Photobiology A: Chemistry, 240, 33-41.

Game, C., Gagnon, M. M., Webb, D., \& Lim, R. (2006). Endocrine disruption in male mosquitofish (Gambusia holbrooki) inhabiting wetlands in Western Australian. Ecotoxicol., 15, 665-672.

Garric, J., \& Ferrari, B. (2005). Pharmaceuticals in aquatic ecosystems. Levels of exposure and biological effects: A review. Revue des sciences del'eau, 18, 307-330.

Gatidou, G., Thomaidis, N., Stasinakis, A., \& Lekkas, T. (2007). Simultaneous determination of the endocrine disrupting compounds nonylphenol, nonylphenol ethoxylates, triclosan and bisphenol $\mathrm{A}$ in wastewater and sewage sludge by gas chromatography-mass spectrometry. Journal of Chromatography A, 1138(1-2), 32-41.

Giri, R. R., Ozaki, H., Ota, S., Takanami, R., \& Taniguchi, S. (2010). Degradation of common pharmaceuticals and personal care products in mixed solutions by advanced oxidation techniques. Int. J.Environ. Sci. Tech., 7(2), 251-260.

Glassmeyer, S. T., Furlorg, E. T., Kolpin, D. W., Cahill, J. D., Zuagg, S. D., Werner, S. L., Meyer, M. T., \& Kryak, D. D. (2005). Transports of chemicals and microbial compounds from known wastewater discharges: Potential for use as indicators of human fecal contamination. Environmental Science and Technology, 39, 5157-5169.

Gogate, P. R., \& Pandit, A. B. (2004). A review of imperative technologies for wastewater. Chemosphere, 73, 848-853.

Gulkowska, A., Leung, H. W., So, M. K., Taniyasu, S., Yamashita, N., Yeung, L. W. Y., Richardson, B. J., Lei, A. P., Giesy, J. P., \& Lam, P. K. S. (2008). Removal of antibiotics from 
wastewater by sewage treatment facilities in Hongkong and Shenzhen, China. Water Research, 42(1-2), 395-403.

Gunnarsson, L., Adolfsson-Erici, M., Björlenius, B., Rutgersson, C., Förlin, L., \& Larsson, D. G. J. (2009). Comparison of six different sewage treatment processes-reduction of estrogenicsubstances and effects on gene expression in exposed male fish. Science of the Total Environment, 407, 5235-5242.

Ha, M. H., Lee, D. H., \& Jacobs, D. R. (2007). Association between serum concentrations of persistent organic pollutants and self-reported cardiovascular disease prevalence: Results from the National Health and Nutrition Examination Survey, 1999-2002. Environmental Health Perspectives, 115, 1204-1209.

Halling-Sørensen, B., Nors Nielsen, S., Lanzky, P. F., Ingerslev, F., Holten Lützhøft, H. C., \& Jørgensen, S. E. (1998). Occurrence, fate and effects of pharmaceutical substances in the environment-a review. Chemosphere, 36(2), 357-393.

Harrison, P. T. C. (2001). Endocrine disrupters and human health. Brit. Med. J., 323, 13171318.

Harrison, E. Z., Oakes, S. R., Hysell, M., \& Hay, A. (2006). Organic chemicals in sewage sludges. Science of the Total Environment, 367, 481-497.

Hartmann, J., Bartels, P., Mau, U., Witter, M., Tumpling, W. V., \& Hofmann, J. (2008). Degradation of the drug diclofenac in water by sonolysis in presence of catalyst. Chemosphere, 70, 453-461.

Heberer, T. (2002). Occurrence, fate, and removal of pharmaceutical residues in the aquatic environment: A review of recent research data. Toxicology Letters, 131, 5-17.

Heberer, T., \& Feldman, D. (2005). Contribution of effluents from hospitals and private households to the total loads of diclofenac and carbamazepine in municipal sewage effluent modelling versus measurement. J.Hazardous Materials, 122,211-218.

Hecker, M., \& Giesy, J. P. (2008). Novel trends in endocrine disrupting testing: The H295R steroidogenesis assay for identification of inducers and inhibitors of hormone production. Analytical and Bioanalytical Chemistry, 390, 287-291.

Hileman, B. (2005). Antiseptic soaps under scrutiny: FDA to assess whether household use leads to bacterial resistance. Chemical and Engineering News, 83, 14 .

Hill, S. S., Shawa, B. R., \& Wuc, A. H. B. (2001). The clinical effects of plasticizers, antioxidants, and other contaminants in medicapolyvinylchloride tubing during respiratory and non-respiratoexposure. Review. Clin. Chim. Acta, 304, 1-8.

Houeto, P., Carton, A., Guerbet, M., Mauclaire, A. C., Gatignol, C., \& Lechat, P. (2012). Assessment of the health risks related to the presence of drug residues in water for human consumption: Application to carbamazepine. Regul Toxicol Pharm, 62(1), 41-48.

Houtman, C. J. (2010). Emerging contaminants in surface water and their relevance for the production of drinking water in Europe. Journal of Integrative Environmental Sciences, 7(4), 271-295.

Hu, A., Zhang, X., Luong, D. Oakes, K. D. Servos, M. R. Liang, R. Kurdi, S. Peng, P. \& Zhou, Y. (2012). Adsorption and Photocatalytic Degradation Kinetics of Pharmaceuticals by $\mathrm{TiO}_{2}$ Nanowires During Water Treatment. Waste Biomass Valor. 
Huang, P. C., Tien, C. J., Sun, Y. M., Hsieh, C. Y., \& Lee, C. C. (2008). Occurrence of Phthalates in sediment and biota: Relationship to aquatic factors and the biotasediment accumulation factor. Chemosphere, 73, 539-544.

Huertas-Perez, J. F., \& Garcia-Campana, A. M. (2008). Determination of Nmethylcarbamate pesticides in water and vegetable samples by HPLC with postcolumn chemiluminescence detection using the luminol reaction. Analytica Chimica Acta, 630(2), 194-204.

Huyghe, E., Matsuda, T., \& Thonneau, P. (2003). Increasing incidence of testicular cancer worldwide: A review. Journal of Urology, 170, 5-11.

Iwuoha, E. I. (2012). Smart nano-dimensional dendritic aptasensor for real-time determination of estrogenic $17 \beta$ - estradiol. International conference and exhibition on biosensors and bioelectronics. May 14-16, 2012 Embassy Suites Las Vegas, USA.

Jackson, J., \& Sutton, R. (2008). Sources of endocrine-disrupting chemicals in urban wastewater, Oakland, CA. Science of the Total Environment, 405, 153-160.

Janex-Habibi, M. L., Bruchet, A., \& Ternes, T. A. (2004). Effect of drinking water treatment and waste water treatment on drug residues. Results of the Poseidon Project. Techniques, Sciences, Methods, 11, 59-67.

Jiao, B., \& Cheng, C. H. K. (2008). Disruption actions of bisphenol A and malachite green on growth hormone receptor gene expression and signal transduction in seabream. Fish Physiology and Biochemistry, 36(2), 251- 261.

Jin, X. L., Jiang, G. B., Huang, G. L., Liu, J. F., \& Zhou, Q. F. (2004). Determination of 4-tertoctylphenol, 4-nonylphenol and bisphenol A in surface waters from the Haihe River in Tianjin by gas chromatography-mass spectrometry with selected ion monitoring. Chemosphere, 56(11), 1113-1119.

Johnson, D. M., Hokanson, D. R., Zhang, Q., Czupinski, K. D., \& Tang, J. (2008). Feasibility of water purification technology in rural areas of developing countries. Journal of Environmental Management, 88, 416-427.

Jones-Lepp, T. L., \& Stevens, R. (2007). Pharmecuticals and personal care products in biosolids/sewage sludge: The interface between analytical chemistry and regulation. Analytical and Bioanalytical Chemistry, 387, 1173.

José, H. J., Gebhardt, W., Moreira, R. F. P. M., Pinnekamp, J., \& Schröder, H. F. (2010). Advanced oxidation processes for the elimination of drugs resisting biological membrane treatment. Ozone: Science \& Engineering, 32, 305-312.

Joseph, L., Heo, J., Park, Y.-G., Flora, J. R. V., \& Yoon, Y. (2011). Adsorption of bisphenol A and 17a-ethinyl estradiol on single walled carbon nanotubes from seawater and brackish water. Deslination, 281, 68-74.

Kasprzyk-Hordern, B., Dinsdale, R. M., \& Guwy, A. J. (2009). The removal of pharmaceuticals, personal care products, endocrine disruptors and illicit drugs during wastewater treatment and its impact on the quality of receiving waters. Water Research, 43(2), 363-380.

Kidd, K. A., Blanchfield, P. J., Mills, K. H., Palace, V. P., Evans, R. E., Lazorchak, J. M., \& Flick, R. W. (2007). Collapse of a fish population after exposure to a synthetic estrogen. Proceeding of the National Academy of Sciences, 104, 8897-8901.

\section{http://repository.uwc.ac.za}


Kim, S. D., Cho, J., Kim, I. S., Vanderford, B. J., \& Snyder, S. A. (2007). Occurrence and removal of pharmaceuticals and endocrine disruptors in South Korean surface, drinking and waste waters. Water Research, 41, 1013-1021.

Kim, I., Yamashita, N., \& Tanaka, H. (2009). Photodegradation of pharmaceuticals and personal care products during $\mathrm{UV}$ and $\mathrm{UV} / \mathrm{H}_{2} \mathrm{O}_{2}$ treatments. Chemosphere, $77,518-$ 525 .

Kinney, C. A., Furlong, E. T., Kolpin, D. W., Burkhardt, M. R., Zaugg, S. D., Werner, S. L., Bossio, J. P., \& Benotti, M. J. (2008). Bioaccumulation of pharmaceuticals and other anthropogenic waste indicators in earthworms from agricultural soil amended with biosolid or swine manure. Environmental Science \& Technology, 42, 1863-1870.

Klavarioti, M., Mantzavinos, D., \& Kassinos, D. (2009). Removal of residual pharmaceuticals from aqueous systems by advanced oxidation processes. Environment International, 35, 402-417.

Klecka, G.M., Staples, C.A., Clark, K.E., Van der Hoeven, N., Thomas, D.E., \& Hentges, S.G., (2009). Exposure analysis of bisphenol-A in surface water Systems North America and Europe. Environmental Science and Technology, 6145-6150.

Kolpin, D. W., Furlong, E. T., Meyer, M. T., Thurman, E. M., Zaugg, S. D., Barber, L. B., \& Buxton, H. T. (2002) Pharmaceuticals, hormones and other organic wastewater contaminants in U.S. streams, 1999-2000: A national reconnaissance. Environmental Science and Technology, 36, 1202-1211.

Kümmerer, K., \& Al-Ahmad, A. (2010). Estimation of the cancer risk to humans resulting from the presence of cyclophosphamide and ifosfamide in surface water. Environmental Science and Pollution Research, 17, 486- 496.

Lafi, W.K., \& Al-Qodah, Z. (2006). Combined advanced oxidation and biological treatment processes for the removal of pesticides from aqueous solutions. Journal of Hazardous Materials, B137: 489:49.

Larsen, T. A., Lienert, J., Joss, A., \& Siegrist, H. (2004). How to avoid pharmaceuticals in the aquatic environment. Journal of Biotechnology, 113, 295-304.

Larsson, D. G. J., de Pedro, C., \& Paxeus, N. (2007). Effluent from drug manufactures contains extremely high levels of pharmaceuticals. J. Hazardous Materials, 148, 751-755.

Le Blanc, F. A., Albrecht, C., Bonn, T., Fechner, P., Proll, G., Pro“, F., II, Carlquist, M., \& Gauglitz, G. (2009). A novel analytical tool for quantification of estrogenicity in river water based on fluorescence labelled estrogen receptor a. Analytical and Bioanalytical Chemistry, 395(6), 1769-1776.

Lear, J. C., Maillard, J. Y., Dettmar, P. W., Goddard, P. A., \& Russell, A. D. (2002). Chloroxylenol- and triclosan-tolerant bacteria from industrial sources. Journal of Industrial Microbiology and Biotechnology, 29, 238-242.

Lee, L. S., Strock, T. J., Sarmah, A. K., \& Rao, P. S. C. (2003). Sorption and dissipation of testosterone, estrogens, and their primary transformation products in soils and sediment. Environmental Science and Technology, 37, 4098-4105.

Li, Y., Niu, J., Yin, L., Wang, W., Bao, Y., Chen, J., \& Duan, Y. (2011). Photocatalytic degradation kinetics and mechanism of pentachlorophenol based on superoxide radicals. Journal of Environmental Sciences, 23(11), 1911-1918.

\section{http://repository.uwc.ac.za}


Lin, A. Y. C., Yu, T. H., \& Lin, C. F. (2008). Pharmaceutical contamination in residential, industrial and agricultural waste streams: Risk to aqueous environments in Taiwan. Chemosphere, 74, 131.

Lin, S., Didi, Y., Jingjing, L., \& Tingting, Z. (2013). Study on the photocatalytic degradation characteristics of Ibuprofen with immobilized $\mathrm{TiO}_{2}$ catalyst. Journal of Nanjing Forestry University, 37(4), 90-94.

Linden, K. G., Rosenfeldt, E. J., \& Kullman, S. W. (2007). UV/ $\mathrm{H}_{2} \mathrm{O}_{2}$ degradation of endocrine-disrupting chemicals in water evaluated via toxicity assays. Water Science and Technology, 55, 313-319.

Lindqvist, N., Tuhkanen, T., \& Kronberg, L. (2005). Occurrence of acidic pharmaceuticals in raw and treated sewages and in receiving waters. Water Research, 39(11), 2219-2228.

Lishman, L., Smyth, S. A., Sarafin, K., Kleywegt, S., Toito, J., Peart, T., Lee, B., Servos, M., Beland, M., \& Seto, P. (2006). Occurrence and reduction of pharmaceuticals and personal care products and estrogens by municipal wastewater treatment plants in Ontario. Canada. Sci. Total Environ., 367, 544-558.

Liu, Z.-h., Kanjo, Y., \& Mizutani, S. (2009). Removal mechanisms for endocrine disrupting compounds (EDCs) in wastewater treatment - physical means, biodegradation, and chemical advanced oxidation: A review. Science of the Total Environment, 407, 731-748.

Liu, Y., Guan, Y. T., Tam, N. F. Y., Mizuno, T., Tsuno, H., \& Zhu, W. P. (2010). Influence of rainfall and basic water quality parameters on the distribution of endocrine-disrupting chemicals in coastal area. Water, Air, and Soil Pollution, 209, 333-343.

Lopez, A., Anna, B., Giuseppe, M., \& John, K. (2003). Kinetic investigation on UV and UV/ $\mathrm{H}_{2} \mathrm{O}_{2}$ degradations of pharmaceutical intermediates in aqueous solution. J. Photochem. Photobiol., 156,121-126.

Lyons, M. (2008). Is there something. In: The water?http:// chicagoist.com/2008/04/17/is_there_someth.php. Accessed 5 Nov 2009).

Machulek, Jr. A., Silvio C. Oliveira, Marly E. Osugi, Valdir S. Ferreira, Frank H. Quina, Renato F. Dantas, Samuel L. Oliveira, Gleison A. Casagrande, Fauze J. Anaissi, Volnir O. Silva, Rodrigo P. Cavalcante, Fabio Gozzi, Dayana D. Ramos, Ana P.P. da Rosa, Ana P.F. Santos, Douclasse C. de Castro, \& Jéssica A. Nogueira. (2013). Application of Different Advanced Oxidation Processes for the Degradation of Organic Pollutants. Chapter 6, INTECH publisher Organic Pollutants-Monitoring, Risk and Treatment. Pp 142.

Mackenzie, C. A., Lockridge, A., \& Keith, M. (2005). Declining sex ratio in a first nation community. Environmental Health Perspectives, 113(10), 1295-1298.

Madhavan, J., Grieser, F., \& Ashokkumar, M. (2010). Combined advanced oxidation processes for the synergistic degradation of ibuprofen in aqueous environments. Journal of Hazardous Materials, 178(1), 202-208.

Maletz, S., Floehr, T., Beier, S., Klümper, C., Brouwer, A., Behnisch, P., Higley, E., Giesy, J. P., Heckerd, M., Gebhardt, W., Linnemann, V., Pinnekamp, J., \& Hollert, H. (2013). In vitro characterization of the effectiveness of enhanced sewage treatment 
processes to eliminate endocrine activity of hospital effluents. Water Research, 47(4), 1545-1557.

Mara, D. D. (2003). Water, sanitation and hygiene for the health of developing nations. Public Health, 452-456.

Marchesini, G. R., Koopal, K., Meulenberg, E., Haasnoot, W., \& Irth, H. (2007). Spreetabased biosensor assays for endocrine disruptors, Biosen. Bioelectron., 22(9-10), 19081915 .

Mastin, J. P. (2005). Environmental cardiovascular disease. Cardiovascular Toxicology, 5, 91-94.

Matos T.A.F., Dias A.L.N., Reis A.D.P., Apolinário da Silva M.R., \& Kondo M.M. (2012). Degradation of Abamectin Using the Photo-Fenton Process. International Journal of Chemical Engineering, Article ID 915724, 7 pages.

Mauricio, R., Diniz, M., Petrovic, M., Amaral, L., Peres, I., Barcel, O. D., \& Santana, F. (2006). A characterization of selected endocrine disruptor compounds in a Portuguese wastewater treatment plant. Environmental Monitoring and Assessment, 118, 75-87.

McClellan, K., \& Halden, R. U. (2010). Pharmaceuticals and personal care products in archived U.S. biosolids from the 2001 EPA national sewage sludge survey. Water Research, 44, 658-668.

Mendez-Arriaga, F., Esplugas, S., \& Gimenez, J. (2008). Photocatalytic degradation of non-steroidal anti-inflammatory drugs with $\mathrm{TiO}_{2}$ and simulated solar irradiation. Water Research, 42, 585-594.

Michael, J. (2001). Are problems with male reproductive health caused by endocrine disruption? Occup Med Educ, 58, 281-288

Moder, M., Braun, P., Lange, F., Schrader, S., \& Lorenz, W. (2007). Determination of endocrine disrupting compounds and acidic drugs in water by coupling of derivatization, gas chromatograph and negative chemical ionization mass spectrometry. Clean Air Soil Water, 35(5), 444-451.

Moldovan, Z. (2006). Occurrences of pharmaceutical and personal care products as micropollutants in rivers from Romania. Chemosphere, 64, 1808-1817.

Montgomery, M. A., \& Elimelech, M. (2007). Water and sanitation in developing countries: Including health in the equation. Environmental Science and Technology, 41, 17- 24 .

Moore, M., Gould, P., \& Keary, B. S. (2003). Global urbanization and impact on health. International Journal of Hygiene and Environmental Health, 206, 269-278.

Mottaleb, M. A., Usenko, S., O’Donnell, J. G., Ramirez, A. J., Brooks, B. W., \& Chambliss, C. K. (2009). Gas chromatography-mass spectrometry screening methods for select UV filters, synthetic musks, alkylphenols, an antimicrobial agent, and an insect repellent in fish. Journal of Chromatography A, 1216(5), 815-823.

Murray, T. J., Lea, R. G., Abramovich, D. R., Haites, N. E., \& Fowler, P. A. (2001). Early Pregnancy. Biologie et Médecine, 5, 80-112.

Naa, S., Ahnb, Y.-G., Cui, M., \& Khim, J. (2012). Significant diethyl phthalate (DEP) degradation by combined advanced oxidation process in aqueous solution. Journal of Environmental Management, 101, 104-110. 
Nakada, N., Tanishima, T., Shinohara, H., Kiri, K., \& Takada, H. (2006). Pharmaceutical chemicals and endocrine disrupters in municipal wastewater in Tokyo and their removal during activated sludge treatment. Water Research, 40(17), 3297-3303.

Nakada, N., Shinohara, H., Murata, A., Kiri, K., Managaki, S., Sato, N., \& Takada, H. (2007). Removal of selected pharmaceuticals and personal care products (PPCPs) and endocrine-disrupting chemicals (EDCs) during sand filtration and ozonation at a municipal sewage treatment plant. Water Research, 41(19), 4373-4382.

Nakashima, T., Ohko, Y., Kubota, Y., \& Fujishima, A. (2003). Photocatalytic decomposition of estrogens in aquatic environment by reciprocating immersion of $\mathrm{TiO}_{2}$-modified polytetrafluoroethylene mesh sheets. Jour nal of Photochemistry and Photobiology, A: Chemistry, 160, 115-120.

Nakonechnya, M., Ikehataa, K., \& El-Dina, M. G. (2008). Kinetics of Estrone Ozone/Hydrogen Peroxide Advanced Oxidation Treatment. Ozone Science and Engineering, 30, 249-255.

Naz, R. K. (2005). Endocrine disruptors: Effects on male and female reproductive systems Boca Raton. FL: CRC Press.

Ning, B., Graham, N., Zhang, Y., Nakonechny, M., \& El-Din, M. G. (2007). Degradation of Endocrine Disrupting Chemicals by Ozone/AOPs. Ozone Science and Engineering, 29, 153176.

Nowotny, N., Epp, B., vonSonntag, C., \& Fahlenkamp, H. (2007). Quantification and modeling of the elimination behavior of ecologically problematic wastewater micropollutants by adsorption on powdered and granulated activated carbon. Environmental Science and Technology, 41(6), 2050-2055.

Oller, I., Malato, S., Sánchez-Pérez, J. A., Gernjak, W., Maldonado, M. I., \& Pérez-Estrada, L. A. (2007). A combined solar photocatalytic-biological field system for the mineralization of an industrial pollutant at pilot scale. Catalysis Today, 122, 150-159.

Oller, I., Malato, S., \& Sánchez-Pérez, J. A. (2011). Combination of advanced oxidation processes and biological treatments for wastewater decontamination-A review. Science of the Total Environment, 409, 4141-4166.

Olujimi, O. O., Fatoki, O. S., Odendaal, J. P., \& Okonkwo, J. O. (2010). Endocrine disrupting chemicals (phenol and phthalates) in the South African environment: A need for more monitoring. Review. Water SA, 36(5), 671-682.

Ortiz de García, S., PintoPinto, G., García Encina, P., \& Mata, R. I. (2013). Consumption and occurrence of pharmaceutical and personal care products in the aquatic environment in Spain. Science of the Total Environment, 444, 451-465.

Palace, V. P., Evans, R. E., Wautier, K. G., Mills, K. H., Blanchfield, P. J., \& Park, B. J. (2009). Interspecies differences in biochemical, histopathological, and population responses in four wild fish species exposed to ethynylestradiol added to a whole lake. Canada J. Fish Aquat Sci, 66, 1920-1935.

Peng, X., Yiyi, Y., Tang, C., Tan, J., Huang, Q., \& Wang, Z. (2008). Occurrence of steroid estrogens, endocrine-disrupting phenols, and acid pharmaceutical residues in urban riverine water of the Pearl River Delta, South China. Science of the Total Environment, 397, 158-166. 
Pereira, V. J., Linden, K. G., \& Weinberg, H. S. (2007). Evaluation of UV irradiation for photolytic and oxidative degradation of pharmaceutical compounds in water. Water Research, 41, 4413-4423.

Perez-Estrada, L. A., Malato, S., Gernjak, W., Aguera, A., Thurman, E. M., \& Ferrer, I. (2005). Photo-Fenton degradation of diclofenac: Identification of main intermediates and degradation pathway. Environmental Science and Technology, 39, 8300-8306.

Petrovic, M., Eljarrat, E., Lopez de Alda, M. J., \& Barcelo, D. (2004). Endocrine disrupting compounds and other emerging contaminants in the environment: A survey on new monitoring strategies and occurrence data. Analytical and Bioanalytical Chemistry, 378, 549.

Petrovic, M., Gonalez, S., \& Barcelo, D. (2003). Analysis and removal of emerging contaminants in wastewater and drinking water. Trends in Analytical Chemistry, 22(10), 685-696.

Pryor, S. W., Hay, A. G., \& Walker, L. P. (2002). Nonylphenol in anaerobically digested sewage sludge from New York State. Environmental Science and Technology, 36, 3678-3682.

Qin, M., Yang, H., Chen, S., Xie, H., \& Guan, J. (2012). Photochemical characteristics of diclofenac and its photooxidation of inclusion complexes with $\beta$-cyclodextrins. Quimica Nova, 35, 559-562.

Rahman, M. F., Yanful, E. K., \& Jasim, S. Y. (2009a). Occurrences of endocrine disrupting compounds and pharmaceuticals in the aquatic environment and their removal from drinking water: Challenges in the context of the developing world. Desalination, 248, 578-585.

Rahman, M. F., Yanful, E. K., \& Jasim, S. Y. (2009b). Endocrine disrupting compounds (EDCs) and pharmaceuticals and personal care products (PPCPs) in the aquatic environment: Implications for the drinking water industry and global environmental health. Journal of Water and Health, 7(2), 224-243.

Rajeswari, R., \& Kanmani, S. (2009). TiO2-based heterogeneous photocatalytic treatment combined with ozonation for carbendazim degradation. Iran. J. Environ. Health. Sci. Eng., 6(2), 61-66.

Rengaraj, S. \& Li, X. Z. (2011). Photocatalytic degradation of Bisphenol A as an endocrine disruptor in aqueous suspension using $\mathrm{Ag}-\mathrm{TiO}_{2}$ catalysts. (In press).

Richardson, S. D., \& Ternes, T. A. (2005). Water analysis: Emerging contaminants and current issues. Analytical Chemistry, 77, 3807-3838.

Roberts, P. H., \& Thomas, K. V. (2006). The occurrence of selected pharmaceuticals in wastewater effluent and surface waters of the lower Tyne catchment. Science of the Total Environment, 356, 143-153.

Rodriguez-Mozaz, S., Lopeéz de Alda, M. J., \& Barcelo, D. (2006). Biosensors as useful tools for environmental analysis and monitoring. Analytical and Bioanalytical Chemistry, 386(4), 1025-1041.

Rogers, J. A., Metz, L., \& Wee Yong, V. (2013). Review: Endocrine disrupting chemicals and immune responses: A focus on bisphenol-A and its potential mechanisms. Molecular immunology, 53, 421-430.

Rosal, R., Rodríguez, A., Perdigón-Meló, J. A., Petre, A., 
Roefer, P., Synder, S., Zegers, R. E., Rexing, D. J., \& Fronk, J. L. (2010). Endocrine disrupting chemicals in a source water. J. Am.WaterWorks Assoc, 92, 52-58. 92.

Rossnera, A., Snyder, S. A., \& Knappe, D. R. U. (2009). Removal of emerging contaminants of concern by alternative adsorbents. Water Research, 43, 3787-3796.

Safe, S. H. (2000). Endocrine disruption and human health-is there a problem? An update. Environmental Health Perspectives, 108(6), 487-493.

Saien, J., \& Khezrianjoo, S. (2008). Degradation of the fungicide carbendazim in aqueous solutions with $\mathrm{UV} / \mathrm{TiO}_{2}$ process: Optimization, kinetics and toxicity studies. Journal of Hazardous Materials, 157, 269-276.

Saien, J., \& Soleymani, A. R. (2007). Degradation and mineralization of direct blue 71 in a circulating upflow reactor by $\mathrm{UV} / \mathrm{TiO}_{2}$ process and employing a new method in kinetic study. Journal of Hazardous Materials, 144, 506- 512.

Saien, J., Ojaghloo, Z., Soleymani, A. R., \& Rasoulifard, M. H. (2011). Homogeneous and heterogeneous AOPs for rapid degradation of Triton X-10o in aqueous media via UV light, nano titania hydrogen peroxide and potassium persulfate. Chemical Engineering Journal, 167, 172-182.

Samir, K. K., Xie, B., Thompson, M. L., Sung, S. W., Ong, S. K., \& Leeuvent, J . V. ( 2006). F ate, transp ort, and biodegradation of natural estrogens in the environment and engineered systems. Environmental Science and Technology, 40, 6537-6546.

Schug, T. T., Janesick, A., Blumberg, B., \& Heindel, J. J. (2011). Endocrine disrupting chemicals and disease susceptibility. The Journal of Steroid Biochemistry and Molecular Biology, $127,204-215$.

Segner, H. (2005). Developmental, reproductive, and demographic alterations in aquatic wildlife: Establishing causality between exposure to endocrine-active compounds (EACs) and effects. Acta Hydrochem. Hydrobiol., 33(1), 17-26.

Sellin, M. K., Snow, D. D., Schwarz, M., Carter, B. J., \& Kolok, A. S. (2009). Agrichemicals in Nebraska, USA, watersheds: Occurrence and endocrine effects. Environmental Toxicology and Chemistry/SETAC, 28, 2443-2448.

Shannon, M. A., Bohn, P. W., Elimelech, M., Georgiadis, J. G., Mariňas, B. J., \& Mayes, A. M. (2008). Science and techonology for water purification in the coming decades. Nature, 452(20), 301-310.

Sharpe, R. M., \& Irvine, D. S. (2004). How strong is the evidence of a link between environmental chemicals and adverse effects on human health? Brit. Med. J., 328, 447-451.

Shemer, H., Kunukcu, Y. K., \& Linden, K. G. (2006). Degradation of the pharmaceutical metronidazole via UV, Fenton and photo-Fenton processes. Chemosphere, 63, 269-276.

Shin, J., Moon, H. J., Kang, H., Kim, T. S., Lee, S. J., Alin, J. Y., Bae, H., Jeung, E. B., \& Han, S. Y. (2007). OECD validation of the rodent Hershberger assay using three reference chemicals 17 a-methyltestorone, procymidore and PP-DDE. Archives of Toxicology, 81, 309-318.

Sin, J.-C., Lam, S.-M., Mohamed, A. R., \& Lee, K.-T. (2012). Degrading endocrine disrupting chemicals from wastewater by $\mathrm{TiO}_{2}$ photocatalysis: A review. International Journal of Photoenergy, 185159, 1-23.

\section{http://repository.uwc.ac.za}


Snyder, S. A., Adham, S., Redding, A. M., Cannon, F. S., Decarolis, J., Oppenheimer, J., Wert, E. C., \& Yoon, Y. (2006). Role of membranes and activated carbon removal of endocrine disruptors and pharmaceuticals. Desalination, 202,156-181.

Snyder, S. A., Adham, S., Redding, A. M., Cannon, F. S., DeCarolis, J., Oppenheimer, J., Wert, E. C., \& Yoon, Y. (2007). Role of membranes and activated carbon in the removal of endocrine disruptors and pharmaceuticals. Desalination, 202(1-3), 156181.

Stasinakis, A. S. (2008) Use of selected advanced oxidation processes (AOPs) for wastewater treatment - a mini review. Water and Air Quality Laboratory, Department of Environment University of the Aegean, University Hill, Mytilene 81100, Greece.

Strauch, K. A. (2011). The impact of pharmaceuticals in the water supply. AAOHN Journal, 59(12), 525-532.

Suarez, S., Carballa, M., Omil, F., \& Lema, J. M. (2008). How are Pharmaceutical and Personal Care Compounds Removed from Urban Wastewaters. Reviews in Environmental Science and Biotechnology, 7, 125 .

Sui, Q., Huang, J., Deng, S., Gang, Y., \& Fan, Q. (2010). Occurrence and removal of pharmaceuticals, caffeine and DEET in wastewater treatment plants of Beijing, China. Water Research, 44, 417-426.

Sumpter, J. P. (2005). Endocrine disruptor in the aquatic environment: A review. Acta Hydrochem. Hydrobiol., 33(1), 9-16.

Swaminathan, M., Muruganandham M., \& Sillanpaa, M. (2013). advanced oxidation processes for wastewater treatment. International Journal of Photoenergy, Article ID 683682, 3 pages.

Swan, S. H., Elkin, E. P., \& Fenster, L. (2000). The question of declining sperm density revisited: An analysis of 101 studies published 1934-1996. Environmental Health Perspectives, 108, 961-966.

Swati, M., Rema, T., \& Joseph, K. (2008). Hazardous organic compounds in urban municipal solid waste from a developing country. Journal of Hazardous Materials, 160, 213.

Tamtam, F., Mercier, F., Le Bot, B., Eurin, J., Dinh, Q. T., Clement, M., \& Chevreuil, M. (2008). Occurrence and fate of antibiotics in the Seine river in various hydrological conditions. Science of the Total Environment, 393, 84-95.

Ternes, T. A., \& Joss, A. (2006). Human pharmaceuticals, hormones and fragrances. New York: IWA Publishing.

Ternes, T. A., Meisenheimer, M. M., Dowell, D., Sacher, F., Brauchg, H., Haist-Gulde, B., Preuss, G., Wilme, U., \& Zulei-Seibert, N. (2002). Removal of pharmaceuticals during drinking water treatment. Environmental Science and Technology, 36, 3855-3863.

Ternes, T. A., Joss, A., \& Siegrist, H. (2004). Scrutinizing pharmaceuticals and personal care products in wastewater treatment. Environmental Science and Technology, 38, 392A. Thorpe, K. L., Cummings, R. I., Hutchinson, T. H., Scholze, M., Brighty, G., Sumpter, J. P., \& Tyler, C. R. (2003). Relative Potencies and combination effects of steroidal estrogens in fish. Environmental Science and Technology, 37, 1142-1149.

Tixier, C., Singer, H. P., Oellers, S., \& Muller, S. R. (2003). Occurrence and fate of carbamazepine, clofibric acid, diclofenac, ibuprofen, ketoprofen, and naproxen in

\section{http://repository.uwc.ac.za}


surface waters. Environmental Science and Technology, 37, 1061-1068. Topp, E., Monteiro, S. C., Beck, A., Coelho, B. B., Boxall, A. B.

A., Duenk, P. W., Kleywegt, S., Lapen, D. R., Payne, M., Sabourin, L., Li, H. X., \& Metcalfe, C. D. (2008). Runoff of pharmaceuticals and personal care products following application of biosolids to an agricultural field. Science of the Total Environment, 396, 52.

Travison, T. G., Araujo, A. B., O’Donnell, A. B., Kupelian, V., \& McKinlay, J. B. (2007). A population level decline in serum testosterone levels in American men. Journal of Clinical Endocrinology and Metabolism, 92, 196-202.

Trenholm, R. A., Vanderford, B. J., Holady, J. C., Rexing, D. J., \& Snyder, S. A. (2006). Broad range analysis of endocrine disruptors and pharmaceuticals using gas chromatography and liquid chromatography tandem mass spectrometry. Chemosphere, 65, 1990-1998.

Trussell, R. R. (2001). Endocrine disruptors and the water industry. Journal of American Water Works Association, 93, 58-65.

Tsai, W.-T., Leeb, M.-K., Suc, T.-Y., \& Yuan, M. C. (2009). Photodegradation of bisphenol-A in a batch $\mathrm{TiO}_{2}$ suspension reactor. Journal of Hazardous Materials, 168, 269-275.

Verma, A., Kaur, H., \& Dixit, D. (2013). Photocatalytic, Sonolytic and Sonophotocatalytic Degradation of 4- Chloro-2-Nitro Phenol. Archives of Environmental Protection., 39(2), 17-28.

Vogel, J. M. (2004). Tunnel vision: The regulation of endocrine disruptors. Political Science, 37, 277-303.

Vogna, D., Marotta, R., Andreozzi, R., Napolitano, A., \& d'Ischia, M. (2004a). Kinetic and chemical assessment of the $\mathrm{UV} / \mathrm{H}_{2} \mathrm{O}_{2}$ treatment of antiepileptic drug carbamazepine. Chemosphere, 54, 497-505.

Vogna, D., Marotta, R., Napolitano, A., Andreozzi, R., \& d'Ischia, M. (2004b). Advanced oxidation of the pharmaceutical drug diclofenac with $\mathrm{UV} / \mathrm{H}_{2} \mathrm{O}_{2}$ and Ozone. Water Research, 38, 414-422.

Vulliet, \& Cren-Olivé, E. (2011). Screening of pharmaceuticals and hormones at the regional scale, in surface and groundwaters intended to human consumption. Environmental Pollution, 159, 2929-2934.

Writer, J. H., Barber, L. B., Brown, G. K., Taylor, H. E., Kiesling, R. L., Ferrey, M. L., Jahns, N. D., Bartell, S. E., \& Schoenfuss, H. L. (2010). Anthropogenic tracers, endocrine disrupting chemicals, and endocrine disruption in Minnesota lakes. Science of the Total Environment, 409, 100-111.

Wu, C. X., Witter, J. D., Spongberg, A. L., \& Czajkowski, K. P. (2009). Occurrence of selected pharmaceuticals in an agricultural landscape, western Lake Erie basin. Water Research, 43, 3407-3416.

Xia, K., Bhandari, A., Das, K., \& Pillar, G. (2005). Occurrence and fate of pharmaceuticals and personal care products (PPCPs) in biosolids. Journal of Environmental Quality, 34, 91104. 
Xiao, R., Diaz-Rivera, D., \& Linda, K. (2013). Weaver factors influencing pharmaceutical and personal care product degradation in aqueous solution using pulsed wave ultrasound. Industrial and Engineering Chemistry Research, 52, 2824-2831.

Xu, B., Gao, N. Y., Rui, M., Wang, H., \& Wu, H. H. (2007). Degradation of endocrine disruptor bisphenol A in drinking water by ozone oxidation. Journal of Hazardous Materials, 138, 526-533.

$\mathrm{Xu}$, J., Wu, L., Chen, W., \& Chang, A. C. (2008). Simultaneous determination of pharmaceuticals, endocrine disrupting compounds and hormone in solids by gas chromatography- mass spectrometry. J. Chromatog., A, 1212, 189.

Xue, N., \& Xu, X. (2006). Composition, distribution and characterization of suspected endocrine-disrupting pesticides in Beying GuanTing Reservoir (GTR). Archives of Environmental Contamination and Toxicology, 50, 463-473.

Yang, L., Yu, L. E., \& Ray, M. B. (2008). Degradation of paracetamol in aqueous solutions by $\mathrm{TiO}_{2}$ photocatalysis. Water Research, 42, 3480-3488.

Yao, S., Li, J., \& Shi, Z. (2010). Immobilization of $\mathrm{TiO}_{2}$ nanoparticles on activated carbon fiber and its photodegradation performance for organic pollutants. Particuology, 8, 272-278.

Yin, H. S., Zhou, Y., \& Ai, S. Y. (2009). Preparation and characteristic of cobalt phthalocyanine modified carbon paste electrode for bisphenol A detection. J. Electroanalytical Chem., 626(1-2), 80-88.

Yoon, Y., \& Lueptow, R. M. (2005). Removal of organic contaminants by RO and NF membranes. J. Membrane Sci., 261, 76-86.

Yoon, Y., Westerhoff, P., Synder, S. A., \& Wert, E. C. (2006a). Nanofiltration and ultrafiltration of endocrine disrupting compounds, pharmaceuticals and personal care products. J. Membrane Sci., 270, 88-100.

Yoon, Y., Westerhoff, P., Synder, S. A., Wert, E. C., \& Yoon, J. (2006b). Removal of endocrine disrupting compounds by nanofiltration and ultrafiltration membranes. Desalination, 202, 16-23.

Yoon, Y., Westerhoff, P., Snyder, S. A., Wert, E. C., \& Yoon, J. (2007). Removal of endocrine disrupting compounds and pharmaceuticals by nanofiltration and ultrafiltration membranes. Desalination, 202(1-3), 16-23.

Yu, C.-P., \& Chu, K.-H. (2009). Occurrence of pharmaceuticals and personal care products along the West Prong Little Pigeon River in east Tennessee, USA. Chemosphere, 75, 1281-1286.

Yu, Z. R., Peldszus, S., \& Huck, P. M. (2008). Adsorption characteristics of selected pharmaceuticals and an endocrine disrupting compound - naproxen, carbamazepine and nonylphenol - on activated carbon. Water Research, 42(12), 28732882.

Yurdakal, S., Loddo, V., Augugliaro, V., Berber, H., Palmisano, G., \& Palmisano, L. (2007). Photodegradation of pharmaceutical drugs in aqueous $\mathrm{TiO}_{2}$ suspensions: Mechanism and kinetics. Catalysis Today, 129, 9-15.

Zala, S. M., \& Penn, D. J. (2004). Abnormal behaviours induced by chemical pollution: A review of the evidence and new challenges. Animal Behaviour, 68, 649-664. 
Zelmanov, G., \& Semiat, R. (2008). Iron(3) oxide-based nanoparticles as catalysts in advanced organic aqueous oxidation. Water Research, 42, 492-498.

Zeng, Z.-Q., Wang, J.-F., Li, Z.-H., Sun, B.-C., Shao, L., Li, W.-J., Chen, J.-F., \& Zou, H.-K. (2013). The advanced oxidation process of phenol solution by $\mathrm{O}_{3} / \mathrm{H}_{2} \mathrm{O}_{2}$ in a rotating packed bed. Ozone: Science \& Engineering, 35, 101-108.

Zhang, Y., \& Zhou, J. L. (2008). Occurrence and removal of endocrine disrupting chemicals in wastewater treatment. Chemosphere, 73, 848-853.

Zhang, W., Li, Y., Qianyuan, W., \& Hongying, H. (2010). Removal of endocrine-disrupting compounds, estrogenic activity, and Escherichia coliform from secondary effluents in a $\mathrm{TiO}_{2}$-Coated photocatalytic reactor. Environmental Engineering Science, 29(3), 196201. 